Revue de sciences sociales sur les arts, la culture et les idées

$2 \mid 2018$

Arpenter la vie littéraire

\title{
De 7 à 280 joueurs
}

Une base de données pour renouveler l'histoire littéraire de la «Pléiade»

From 7 to 280 Players. A Database to Reassess the Literary History of La Pléiade De 7 a 280 jugadores. Una base de datos para renovar la historia literaria de la «Pléiade»

\section{Florence Bonifay}

\section{OpenEdition} Journals

Édition électronique

URL : http://journals.openedition.org/bssg/219

DOI : 10.4000/bssg. 219

ISSN : 2490-9424

Éditeur

Presses universitaires de Vincennes

Référence électronique

Florence Bonifay, « De 7 à 280 joueurs », Biens Symboliques / Symbolic Goods [En ligne], 2 | 2018, mis en ligne le 12 avril 2018, consulté le 04 mars 2021. URL : http://journals.openedition.org/bssg/219 ; DOI : https://doi.org/10.4000/bssg.219 


\title{
De 7 à 280 joueurs From 7 to 280 Players
}

\section{Une base de données pour renouveler l'histoire littéraire de la « Pléiade »}

\section{A Database to Reassess the Literary History of La Pléiade}

\author{
Florence Bonifay \\ traduction | translation \\ Michelle Arriss | Delaina Haslam | Séverine Sofio
}

Même si la « Pléiade $^{1}$ » hante encore les manuels du secondaire pour désigner un groupe de sept poètes du milieu du $x{ }{ }^{e}$ siècle, il est entendu depuis bien longtemps qu'elle n'est qu'un mythe (Balmas 1965 ; Lebègue 1966) : cette vue de l'esprit de Ronsard, quoique fugace ${ }^{2}$, frappa l'imagination d'une poignée de ses contemporains et fut, surtout, une étiquette commode pour les historiens de la

1 Nous mettons des guillemets lorsqu'il s'agit d'utiliser le mot pour désigner le mouvement littéraire que des historiens de la littérature et concepteurs de manuels scolaires désignent avec cette étiquette. Nous utilisons les italiques lorsqu'il s'agit de renvoyer au mot Pléiade tel qu'il a été utilisé par quelques poètes du XVle siècle.

2 Ronsard n'utilise qu'une fois le mot, en 1556, dans l'« Elegie de P. de Ronsard a Chretophle de Choiseul », poème liminaire qu'il offre à son ami Remy Belleau pour son recueil des Odes d'Anacreon Teien, traduites de Grec en Francois (1556). II n'y cite pas une liste de sept noms mais signale juste que Belleau intègre « la brigade / Des bons, pour accomplir la setieme Pliade [sic] ».
While the "Pléiade"1 still haunts school textbooks to refer to a group of seven mid sixteenth-century poets, it has long been understood as nothing more than a myth (Balmas 1965; Lebègue 1966): this creation of Ronsard, although elusive ${ }^{2}$ captured the imagination of a handful of his contemporaries and was, above all, a convenient label for literary historians during the centuries that followed. In

1 Quotation marks are being used for the word "Pléiade" when it refers to the literary movement that historians of literature and school textbook writers have labelled this way, whereas italics are used when it comes to referring to the word Pléiade as it was used by a few poets of the sixteenth century.

2 Ronsard only used the word once, in 1556, in the "Elegie de P. de Ronsard a Chretophle de Choiseul," a liminary poem that he gave to his friend Remy Belleau for his collection titled Odes d'Anacreon Teien, traduites de Grec en Francois (1556). In it, he doesn't mention a list of seven names, but simply observes that Belleau joined "la brigade / Des bons, pour accomplir la setieme Pliade [sic]" (the brigade / Of good men, to complete the seventh Pleiad) 
littérature des siècles suivants. Dans les études seiziémistes récentes, Emmanuel Buron a condamné l'usage du mot au début des années $2000^{3}$. II reste néanmoins usité par commodité - mis à distance et entouré de précautions - non pas pour désigner un groupe historique mais une mouvance esthétique.

Presque quatre-vingts ans après la monumentale Histoire de la Pléiade d'Henri Chamard (Chamard 1939-1940), nous avons voulu revisiter l'histoire de la «Pléiade » sous l'angle de la sociabilité telle qu'elle est représentée par les poètes. Le dépouillement de 312 recueils de poésie, parus entre 1549 et 1586, nous a permis d'identifier et de saisir 2200 textes dans lesquels les poètes se nomment les uns les autres et mettent en scène leurs relations. La création d'une base de données nous a alors semblé nécessaire afin de relier ces textes entre eux et de faciliter l'exploration des méandres de ce réseau extrêmement riche (qui cite ou évoque qui ? quand ? dans quel recueil ? à quelle date?), tout en donnant accès au contenu des textes. C'est ainsi que la base «RéseauxPoètesXVI " est née et a constitué un outil de travail central pour nos années de doctorat (voir Bonifay 2016).

Après avoir présenté la constitution et l'organisation de cette base de données, nous focaliserons notre attention sur deux points. Nous montrerons, d'une part, quels peuvent être quelques-uns des apports de cette base informatique à l'étude des représentations des sociabilités poétiques de la seconde moitié $\mathrm{du} x \mathrm{Xl} \mathrm{l}^{\mathrm{e}}$ siècle, afin de mieux situer le sous-groupe que l'histoire littéraire a retenu sous le nom de «Pléiade ». Nous soulignerons, d'autre part, que l'ensemble des données de la base met en valeur l'intense activité réflexive des poètes sur le groupe social spécifique qu'ils composent.

3 Emmanuel Buron (2001). «Pléiade » (art.). In Dictionnaire des lettres françaises. Le XVI siècle. Paris, Livre de Poche : 953 : « Pléiade. Terme équivoque, et qu'il serait utile d'abandonner, par lequel les historiens de la littérature désignent l'école de Ronsard. " recent sixteenth century studies, Emmanuel Buron condemned the use of the word at the beginning of the 2000s. ${ }^{3}$ It remains, nevertheless, in use out of convenience - put at arm's length and surrounded by precautions - to refer not to a historical group but to an aesthetic movement.

Almost eighty years after Henri Chamard's monumental work Histoire de la Pléiade (Chamard 1939-1940), I wanted to revisit the history of the "Pléiade" from the angle of sociability as represented by poets. Scanning 312 poetry collections published between 1549 and 1586 allowed me to identify and enter 2,200 texts in which poets name each other and reveal their relationship to one another. I then felt it necessary to create a database in order to establish links between the texts and facilitate exploration of the twists and turns of this extremely rich network (who cites or mentions who? When? In which collection? On what date?), while at the same time allowing access to the content of the texts. This is how the "RéseauxPoètesXVI" database came into being and constituted a central tool for my PhD research (see Bonifay 2016).

After presenting the composition and organization of the database, we will focus on two points. On the one hand, we will demonstrate some of the possible ways in which it can support the study of representations of poetic sociability in the second half of the sixteenth century, in order to better situate the sub-category which literary history has labelled the "Pléiade." We will emphasize, on the other hand, how our full data highlights the intense reflexive activity of the poets on the specific social group they made up.

3 Emmanuel Buron (2001). "Pléiade" (Art.). In Dictionnaire des lettres françaises. Le XVI siècle. Paris, Livre de Poche: 953: "Pléiade. Terme équivoque, et qu'il serait utile d'abandonner, par lequel les historiens de la littérature désignent l'école de Ronsard' (Pléiade: A questionable term, and one which it would be advisable to discontinue, used by literary historians to refer to the school of Ronsard). 


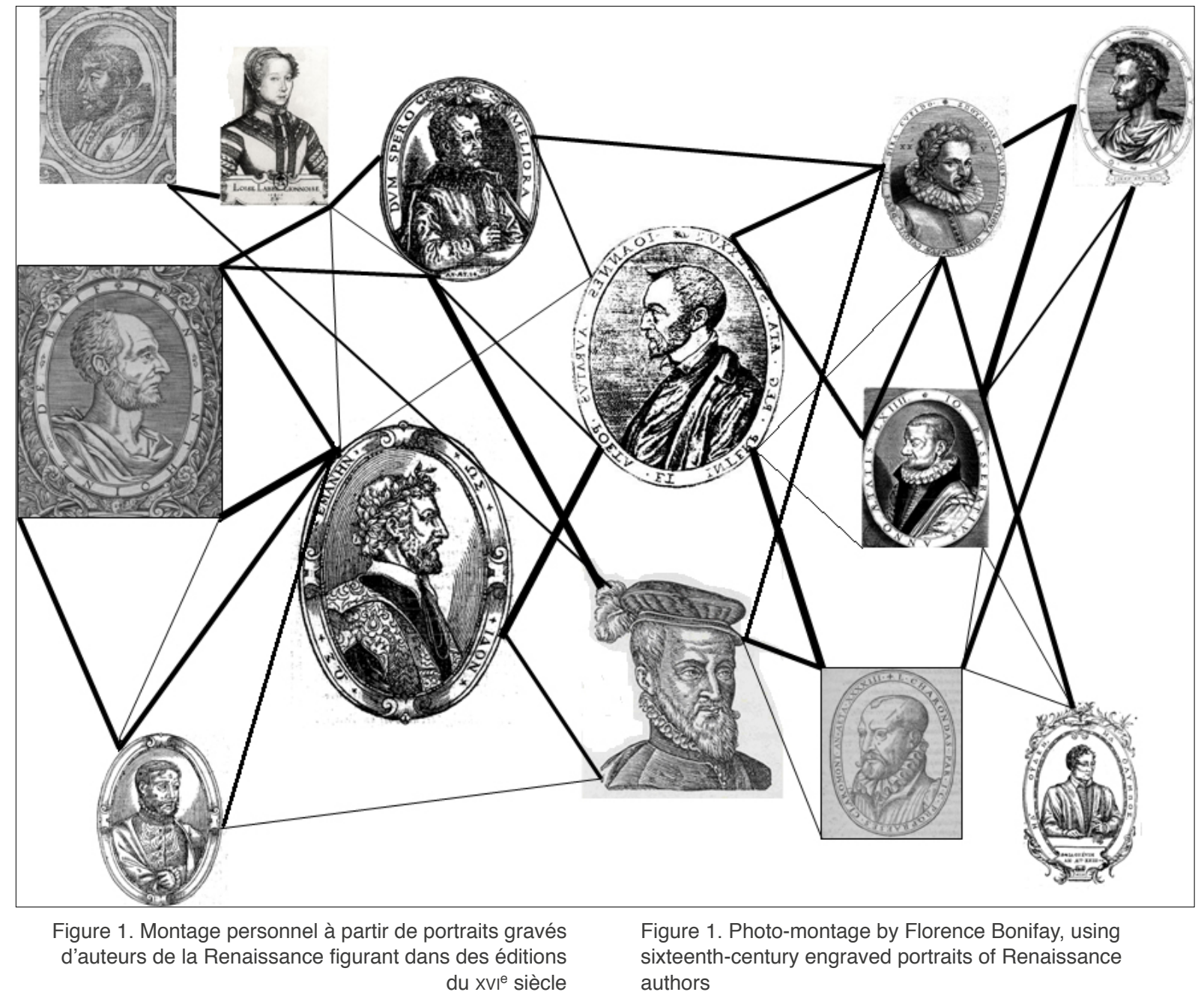




\section{Constitution du corpus et de la base de données}

Bornes historiques et nature du corpus

La période historique à laquelle nous nous intéressons commence en 1549, année de publication de La Deffence, et illustration de la langue françoyse par Joachim Du Bellay. Considéré comme le manifeste de la «Pléiade », l'opuscule « tente de préciser les cadres d'une poésie encore inédite [...] et, par-delà, d'instituer une nouvelle classe de poètes ", patriotes car écrivant en français, héroïques, philosophes et auxiliaires du pouvoir royal centralisateur, souligne Jean-Charles Monferran dans l'édition 2007 de La Deffence ${ }^{4}$. Ce texte, qui veut imposer une rupture dans l'histoire de la poésie, constitue une nouveauté, précise Jean Vignes : « jusqu'ici en effet, l'évolution du goût poétique s'était produite sans rupture marquée, chaque nouvelle génération affirmant son respect pour les maîtres des générations précédentes » (2007 : 103). L'analyse comparée que fait Francis Goyet du marotique ${ }^{5}$ Art poetique François (1548) de Sébillet et de La Deffence (1549) de Du Bellay ne dit pas autre chose : Sébillet présente une « façon graduelle de monter aux sommets poétiques » (Goyet $2003: 114$ ) tandis que Du Bellay est un «blanc-bec » qui « endosse [...] le rôle, la persona d'un auteur confirmé » (Goyet $2003: 124$ ) et refuse l'apprentissage graduel en se positionnant directement au sommet de l'échelle.

Le Tombeau 6 de Ronsard (1586), réuni par son ami Claude Binet quelques mois après sa mort et comptant une soixantaine de

4 Joachim Du Bellay (2007). La Deffence, et illustration de la langue françoyse \& L'Olive, éd. J.-C. Monferran \& E. Caldarini. Genève, Droz : 10.

5 L'Art poetique François de Thomas Sébillet tire en grande partie ses exemples de lœuvre de Clément Marot et défend son esthétique.

6 Un tombeau poétique est un recueil de poèmes écrits par plusieurs contributeurs pour honorer la mémoire d'un illustre défunt. Les décès de

\section{Composition of the Corpus and Database}

\section{Historical Border Markers and Nature of the Corpus}

The historical period we are interested in began in 1549, the year of publication of Joachim Du Bellay's Deffence, et illustration de la langue françoyse. Considered as the manifesto of the "Pléiade," the pamphlet "attempts to define a form of poetry that is as yet unknown... and, beyond this, to establish a new class of poets" who were patriotic since they wrote in French, heroic, philosophers, and accessories to centralizing royal power, as Jean-Charles Monferran explains in the 2007 edition of the Deffence ${ }^{4}$. This text, which intended to disrupt the history of poetry, was something new, as Jean Vignes states: "Indeed, up until that point, the evolution of poetic taste had occurred without significant rupture, each new generation affirming its respect for the masters of the previous generations" (2007: 103). The comparative analysis carried out by Francis Goyet on Sébillet's "marotic"5 Art poetique François (1548) and Du Bellay's Deffence (1549) concurs: Sébillet presents a "means of gradual ascent to the poetic heights" (Goyet 2003: 114) while Du Bellay is a novice who "takes on... the role, the persona of an established poet" (Goyet 2003: 124) and refuses gradual learning, placing himself directly at the summit.

Ronsard's Tombeau 6 (1586) with sixty contributors, compiled by his friend Claude Binet a few months after his death, marks the

4 Joachim Du Bellay (2007). La Deffence, et illustration de la langue françoyse \& L'Olive, eds J.-C. Monferran and E. Caldarini. Geneva, Droz: 10.

5 L'Art poetique François by Thomas Sébillet largely draws examples from the work of Clément Marot and defends its aesthetics.

6 A tombeau poétique is a collection of epitaphs written by several contributors to honour the memory of an important person after death. The deaths of 
signatures, marque la borne finale de notre étude. La carrière de l'ami et rival de la première heure de Du Bellay, menant le même combat que lui au début des années 1550, inventant l'image d'une «Pléiade » de sept poètes et publiant de la poésie jusqu'à sa mort, fait donc l'unité de la période choisie. Certes, Jean Dorat (mort en 1588), Jean-Antoine de Baiff (mort en 1589) et Pontus de Tyard (mort en 1605) - qui font partie de la troupe des novateurs dans les années 1550 - survivent de quelques années à Ronsard. Toutefois, ils ne produisent plus guère de poésie (Tyard, sur la fin de sa vie, s'intéresse uniquement à la religion et à la philosophie) ni de pièces de contact avec des poètes. Par ailleurs, leur décès ne donne pas lieu à un bilan aussi monumental que le Tombeau de Ronsard qui fait état de la notoriété du Vendômois mais fournit aussi des regards rétrospectifs sur toute une période poétique que certains craignent désormais révolue.

Sur cette période longue, nous ne nous sommes intéressée qu'aux recueils poétiques imprimés, pour une raison évidente de commodité mais aussi parce que la publication imprimée est fortement valorisée par Ronsard et ses amis. Leurs déclarations ne doivent pas faire oublier que l'impression n'est pas la seule voie d'accès à la grandeur, comme en témoigne Mellin de Saint-Gelais, aumônier du roi sous François $1^{\text {er }}$ et Henri II, qui fit le choix jusqu'à sa mort en 1558 de ne pas faire sortir des presses un recueil de ses œuvres. Toutefois, la publication imprimée soutient leur volonté de conquête des droits de l'auteur et de conquête de l'espace public ${ }^{7}$. En effet, ne pas publier

Louise de Savoie (1531) et du dauphin François (1536) donnent lieu à la composition des premiers tombeaux poétiques de la littérature française. Sur cette pratique sociale collective et sur ses enjeux littéraires et politiques, voir Amaury Flégès (1994; 2004).

7 Dans la suite de ce qu'a opéré Clément Marot, comme l'a montré Guillaume Berthon (2014) final boundary of our study. The career of Du Bellay's friend and original rival, leading the same battle as him at the beginning of the 1550s, inventing the image of a "Pléiade" of seven poets, and publishing poetry until his death, thus ensures the coherence of the chosen period. Jean Dorat (who died in 1588), Jean-Antoine de Baif (who died in 1589) and Pontus de Tyard (who died in 1605 ) - who formed part of the group of innovators in the 1550s outlived Ronsard by several years. After the latter's death, however, they scarcely produced any further poetry (at the end of his life, Tyard was only interested in religion and philosophy) or referenced other poets. Besides, their deaths did not trigger as monumental a tribute as Ronsard's Tombeau - a collection that not only reflects the renown of the poet, but also provides retrospective perspectives on a whole period of poetry which some feared was now over.

Over this long period, I focused on printed poetry collections, for the obvious reason of convenience but also because print publication was highly valued by Ronsard and his friends. Their declarations should not obscure the fact that print was not the only route to success, as demonstrated by Mellin de Saint-Gelais, Francis I and Henry II's Grand Chaplain of France, who chose not to publish a printed collection of his works until his death in 1558. Nevertheless, print publication used to reinforce their desire to obtain author's rights and conquer the public space. ${ }^{7}$ Indeed, according to Du Bellay (Deffence, Book II, chap. 2) not publishing exposed the poet to plagiarism, and it harmed the public good, according to Olivier de

Louise de Savoie (1531) and Dauphin François (1536) inspired the first tombeaux poétiques in French literature. On this collective social practice and its effects on literature and politics, see Amaury Flégès $(1994 ; 2004)$.

7 As Clément Marot had done, like Guillaume Berthon shows (2014). 
expose au plagiat, selon Du Bellay (Deffence, Livre II, chap. 2) et fait du tort au bien public selon Olivier de Magny qui déplore que SaintGelais n'imprime pas ses œuvres ${ }^{8}$ et qui estime qu'Étienne Jodelle ne fait pas son « juste devoir » en tardant à publier ses vers ${ }^{9}$. Le refus de la publication imprimée empêche, en outre, de passer à la postérité. Enfin, au regard de l'idéal viril et héroïque de Du Bellay et de Ronsard, c'est une lâcheté. Le poète vendômois fustige ainsi, dans le «Au lecteur » de ses Odes de 1550, les « sciamaches", c'est-à-dire les combattants en chambre qui n'osent pas faire entrer leurs œuvres dans l'arène publique. De son côté, Du Bellay affirme qu'un poète qui ne publie pas ne peut prétendre à la première place, de sorte que Mellin de Saint-Gelais « pour n'avoir encores rien mis en lumiere soubz son nom, ne merite qu'on luy donne le premier lieu ${ }^{10} »$. Parce que nous nous intéressons à la dimension publicitaire des représentations de la sociabilité littéraire ${ }^{11}$, nous avons joué le jeu de la majeure partie des poètes de la "Pléiade " (à l'exception de Jodelle, très réticent à publier) en ne tenant compte que des publications imprimées. Ce faisant, nous pouvons observer comment les poètes s'entraident pour la conquête d'un marché, Ronsard écrivant par exemple "Au lecteur », en liminaire de La Bergerie de Belleau (1576) : "lecteur si tu peux entre les Muses vivre / Achepte moy Belleau ${ }^{12}$ ».

8 Olivier de Magny (1999). «Pièce XXVI des Gayetez » (1554). In François Rouget (dir.). œuvres Poétiques I. Paris, Champion : 341-343.

9 Olivier de Magny (1999). «A Estienne Jodelle parisien » (1554) du recueil Les Gayetez. œuvres Poétiques I. Paris, Champion : 298-300.

10 Joachim Du Bellay (2007). La Deffence, et illustration de la langue françoyse \& L'Olive, éd. J.-C. Monferran \& E. Caldarini. Genève, Droz : 123-124.

11 Au sens où il s'agit de faire connaître, sans doute au-delà du milieu de la cour, un ensemble de poètes dont il est suggéré qu'ils forment une cohorte nombreuse et, partant, de faire vendre leurs recueils.

12 Pierre de Ronsard (2001). "Au lecteur. P. de Ronsard » (1572) en liminaire de La Bergerie de Belleau dans Remy Belleau, œuvres poétiques IV, éd. G. Demerson. Paris, Champion : 84, v. 13-14.
Magny, who is critical of Saint-Gelais for not printing his works, and who believes that Etienne Jodelle failed to do his "fair duty" in delaying the publication of his verse. ${ }^{9}$ Refusal to publish also prevented the work from being passed on to posterity. Compared to the virile and heroic ideal of Du Bellay and of Ronsard, it was cowardice. In his "Notes to the Reader" in his 1550 Odes, Ronsard thus berates the "sciamaches": indoor combatants who dare not put their work into the public arena. For his part, Du Bellay states that a poet who does not publish cannot attain the highest success, such as Mellin de Saint-Gelais: "pour n'avoir encores rien mis en lumiere soubz son nom, ne merite qu'on luy donne le premier lieu"10 (for not having brought anything to light under his name, does not merit us giving him first place). Since I am interested in the representations of literary sociability as an advertising medium, ${ }^{11}$ I played along with the game of most of the "Pléiade" poets (except Jodelle, who was very reluctant to publish) by only taking print publications into account. In so doing, I observed how the poets helped each other to conquer the market - with, for example, Ronsard writing in a liminary text to Belleau's La Bergerie (1576): "lecteur si tu peux entre les Muses vivre / Achepte moy Belleau"12 (reader if you can live among the Muses / Accept me Belleau).

8 Olivier de Magny (1999). "Pièce XXVI of the Gayetez" (1554). In CEuvres Poétiques I, ed. F. Rouget. Paris, Champion: 341-343.

9 Olivier de Magny (1999). "A Estienne Jodelle parisien" (1554) from the Les Gayetez collection. In CEuvres poétiques I, ed. F. Rouget. Paris, Champion: 298-300

10 Joachim Du Bellay (2007). La Deffence, et illustration de la langue françoyse \& L'Olive, eds J.-C. Monferran and E. Caldarini. Geneva, Droz: 123-124.

11 In the sense that it is a case of spreading (most likely beyond the milieu of the court) the word about a group of poets - presented as numerous - to sell their printed collections.

12 Pierre de Ronsard (2001) "Au lecteur. P. de Ronsard" as a liminary text to La Bergerie by Belleau (1572). In Remy Belleau, CEuvres poétiques IV, ed. G. Demerson. Paris, Champion: 84, v. 13-14. 


\section{Réseaux de citations, reconnaissance et économie du don}

Pour appréhender les représentations des relations entre poètes autour de la "Pléiade ", nous avons décidé de focaliser notre attention sur le processus de nomination. En effet, dire le nom consiste à reconnaître l'existence de l'autre, de sorte que nommer relève autant d'une logique d'élection que d'une logique d'exclusion. Le seul poème dans lequel Ronsard imagine une Pléiade de sept bons poètes en témoigne. Imprimée en 1556, l'« Élégie de P. de Ronsard, à Chretophle de Choiseul, Abbé de Mureaux » renvoie aux premières publications de Ronsard et de Du Bellay qui correspondent historiquement à l'avènement du roi Henri II $^{13}$ :

Du regne de HENRY, cinq ou six seulement,

Vindrent, qui d'un acord moderé doucement,

Et d'un pouce atrempé firent doctement bruire

Maintenant la guitterre, et maintenant la lyre,

Et maintenant le luc, et oserent tenter

Quelque peu la trompette affin de haut chanter.

Incontinent apres, une tourbe inconnue

De serfz imitateurs, pesle mesle est venue

Se ruer sans esgard, laquelle a tout gasté

Cela que les premiers avoient si bien chanté.

13 Henri II monte sur le trône en 1547. La Deffence, et illustration de la langue françoyse est publié en 1549. Dès 1547, Ronsard et Du Bellay publient un poème dans les CEuvres poetiques de Jacques Peletier du Mans.

\section{Network of Quotations, Recognition, and Gift Economy}

To apprehend representations of relations between poets in the context of the "Pléiade," we decided to focus our attention on the process of naming. Indeed, to say a name is to recognize the existence of the other, in such a way that naming participates as much of a logic of choice as of a logic of exclusion. The only poem in which Ronsard imagines a Pléiade of seven fine poets attests to this. Printed in 1556, the "Élégie de P. de Ronsard, à Chretophle de Choiseul, Abbé de Mureaux" refers back to the first publications of Ronsard and Du Bellay, which correspond historically to the accession of King Henry II in $1547^{13}$ :

Du regne de HENRY, cinq ou six seulement,

Vindrent, qui d'un acord moderé doucement,

Et d'un pouce atrempé firent doctement bruire

Maintenant la guitterre, et maintenant la lyre,

Et maintenant le luc, et oserent tenter

Quelque peu la trompette affin de haut chanter.

Incontinent apres, une tourbe inconnue

De serfz imitateurs, pesle mesle est venue

Se ruer sans esgard, laquelle a tout gasté

Cela que les premiers avoient si bien chanté. ${ }^{14}$

(In the reign of HENRY, came only five or six, Who, with a soft, measured chord

And gentle thumb, carefully struck a sound

First from the guitar, and now the lyre,

13 La Deffence, et illustration de la langue françoyse was published in 1549 From 1547, Ronsard and Du Bellay published a poem in Jacques Peletier du Mans' CEuvres poetiques.

14 Pierre de Ronsard (1935). CEuvres complètes VIII, ed. P. Laumonier. Paris, Nizet: $352-354$, v. $15-24$ 
Selon la vision ronsardienne de l'histoire littéraire, après cette première « moisson d'enfans, / Gentilz, doctes, bien-nez » (v. 36-

$37)$, la production de la « France mere » s'est tarie. Et,

Meintenant à son tour, fertile, elle commence A s'enfler tout le sein d'une belle semence,

Et ne veut plus soufrir que son limon oyseux De chardons se herisse, et de buissons ronceux Te concevant, Belleau, qui viens en la brigade Des bons, pour accomplir la setieme Pliade. Qui as (comme bien-né) ton naturel suivy, Et que les Muses ont naïvement ravy Aux contemplations de leurs sciences belles ${ }^{14}$.

14 Pierre de Ronsard (1935). CEuvres complètes VIII, éd. P. Laumonier. Paris, Nizet : 352-354, v. 15-24 puis 41-49.
And now the lute, and dared to try

A little trumpet so as to sing a fine song

Immediately after, an unknown crowd

Of imitating serfs, came pell-mell>

Rushing, paying no heed, they destroyed all

That which the first had sung so well. ${ }^{15}$ )

According to the Ronsardian vision of literary history, after this first "moisson d'enfans, / Gentilz, doctes, bien-nez" (yield of children, / Noble, learned, well born) (v. 36-37), the production of "mother France" dried up. And,

Meintenant à son tour, fertile, elle commence A s'enfler tout le sein d'une belle semence,

Et ne veut plus soufrir que son limon oyseux

De chardons se herisse, et de buissons ronceux

Te concevant, Belleau, qui viens en la brigade

Des bons, pour accomplir la setieme Pliade.

Qui as (comme bien-né) ton naturel suivy,

Et que les Muses ont naïvement ravy

Aux contemplations de leurs sciences belles. ${ }^{16}$

(Now in turn fertile, her whole breast

Begins to swell with a beautiful seed,

And wishes to suffer no more as her idle silt

Hurt herself on thistles, and knotted bushes

Perceiving you, Belleau, who joins the brigade

Of the mighty, to complete the seventh Pliade.

Who has [of those well born] your natural flow

And which the Muses naively delighted

At the thought of their beautiful science.)

15 NB: This translation has been carried out by BSSG.

16 Pierre de Ronsard (1935). CEuvres complètes VIII, ed. P. Laumonier. Paris, Nizet: $352-354$, v. 41-49 
Ces vers délivrent une vision de l'histoire littéraire avançant par cycles alternés d'abondance et de sècheresse, et reposent sur des oppositions de valeurs : la rareté (« cinq ou six seulement », plus le « setieme ») face à la masse («tourbe [...] pesle mesle [...] venue / Se ruer »), le haut (" haut chanter ») face au bas (ceux qui se « rue[nt] » dans le « limon oyseux »), le savoir (« doctes », " doctement ») face à la bêtise et à l'indélicatesse (" sans esgard [...] a tout gasté »), l'audace (« oserent tenter ») face à la pâle imitation (" serfz imitateurs ») et la noblesse de sang (" bien-nez », «bien né ») face à la fange (" serfz », "limon oyseux »). Rédigés et publiés par un poète qui se veut chef de file ${ }^{15}$, à l'instar de Du Bellay, ils témoignent d'une vision élitiste de la poésie, articulée à des éléments tangibles comme la noblesse de naissance, le bagage savant et le talent musical, le tout étant sublimé par un " je-ne-sais-quoi » désigné comme un don des Muses. Dans ce cadre-là, la nomination joue un rôle important : Remy Belleau, désigné par son nom, est distingué de la " tourbe inconnue ", pour être intégré dans le petit collectif des très « bons » (v. 46) qui composent la Pléiade au sein du groupe des bons de la Brigade.

Nommer un confrère apparaît alors comme un signe de reconnaissance de son talent et de son droit à figurer dans les imprimés destinés à passer à la postérité. Du Bellay le souligne :

15 « [Q]uand tu m'appelleras le premier auteur Lirique François, \& celui qui a guidé les autres au chemin de si honneste labeur, lors tu me rendras ce que tu me dois », écrit Ronsard dans le « Au lecteur » qui ouvre Les Quatre Premiers Livres des Odes publiés en 1550
These lines deliver a vision of literary history which advances in alternating cycles of abundance and drought; it is based on oppositions of values: scarcity ("cinq ou six seulement" then the "setieme") and mass ("tourbe ... pesle mesle [...] venue / Se ruer"); high ("haut chanter") and low (those who "rue[nt]", rush, in the "limon oyseux", dregs of society); knowledge ("doctes," "doctement") and stupidity and tactlessness ("sans esgard... a tout gasté"); bravery ("oserent tenter") and pale imitation ("serfz imitateurs"); and nobility of blood ("bien-nez", "bien né") and the dregs of society ("serfz", "limon oyseux"). Written and published by a poet who saw himself as leader, ${ }^{17}$ as Du Bellay did, these lines reflect an elitist vision of poetry, hinging on tangible elements such as nobility of birth, learned skills, and musical talent, all sublimated by a je ne sais quoi referred to as a gift from the Muses. In this context, naming plays an important role: Remy Belleau, referred to by name, is distinguished from the tourbe inconnue (unknown crowd), and introduced into the small collective of fine ("bons") poets which form the Pléiade within the group of fine poets who form the Brigade.

To name a fellow poet thus appears as a sign of recognition of his talent and his right to be published and recorded for posterity. Du Bellay highlights this:

17 «[Q]uand tu m'appelleras le premier auteur Lirique François, \& celui qui guidé les autres au chemin de si honneste labeur, lors tu me rendras ce que tu me dois," ("The day you call me the first author of French Lyric poetry, and he who has guided others on the path of such honest toil, then you will give me back what you owe me") wrote Ronsard in the "Note to the Reader" which opens Les Quatre premiers livres des Odes, published in 1550. 
Qui eust sceu de Mars les enfans,

Leurs lauriers, leurs chars triumphans,

Si ores l'envieux silence

A leurs noms faisoit violence ${ }^{16}$ ?
Qui eust sceu de Mars les enfans,

Leurs lauriers, leurs chars triumphans,

Si ores l'envieux silence

A leurs noms faisoit violence ${ }^{18}$

(Who had known of Mars the children,

Their laurels, their triumphant chariots

So golden the envious silence

In their names was making violence?)

Le système de rimes révèle la hantise du « silence » qui apparaît comme une « violence » puisqu'il engloutit le nom dans l'oubli. Cette violence, pourrait-on dire avec Pierre Bourdieu, est « symbolique » dans la mesure où elle a une « double dimension immatérielle et relationnelle », comme le résume Pascal Durand dans l'article «Capital symbolique » du Lexique socius. Àl'inverse, par conséquent, la nomination peut être assimilée à un « bien symbolique » que s'échangent les poètes et qui construit de la réputation, réputation singulière (lorsqu'un seul confrère est nommé) ou réputation

collective (lorsque c'est toute une liste de poètes qui est louée).

À vrai dire, l'entreprise est à la fois individuelle et collective. Pour s'assurer un passage personnel à la postérité, les poètes de la génération 1550, poursuivant la « conquête de la paternité du tout de l'œuvre par l'auteur » à laquelle a fortement contribué Clément Marot dans les années 1530-1540 (Alduy 2007 : 98), s'emploient à écrire leur nom au fronton de leurs œuvres ${ }^{17}$ et

16 Joachim Du Bellay (1983) [1912]. « A Carles. Ode XII» (1549). CEuvres poétiques III, éd. H. Chamard. Paris, STFM/Nizet : 132, v. 29-32.

17 Michèle Clément parle d'une « épiphanie du nom d'auteur au XVI siècle » et souligne que la présence du nom d'auteur sur la page de titre est « de plus en plus fréquente à partir de 1520 » : « Le nom d'auteur apparaît progressivement
The rhyme scheme reveals the dread of "silence," which appears as a "violence" since it has smothered the name into oblivion. We could say, after Pierre Bourdieu, that this violence is "symbolic" since it has a "double dimension that is both immaterial and relational," as summarized by Pascal Durand in an article titled "Capital symbolique" in the Lexique socius. Conversely, therefore, naming can be seen as a "symbolic good" exchanged by poets that builds reputation - either individual (when a single colleague is named) or collective (when it is a whole list of poets that is lauded).

In fact, the endeavour is both individual and collective. Poets of the 1550 generation, pursuing the "conquest of authorship of all work by a writer" to which Clément Marot had greatly contributed in the 1530s and 1540s (Alduy 2007: 98), would write their name on the frontispiece of their works ${ }^{19}$ and refer to themselves in their verse

18 Joachim Du Bellay (1983) [1912]. "A Carles. Ode XII" (1549). CEuvres poétiques III, ed. H. Chamard. Paris, STFM/Nizet: 132, v. 29-32.

19 Michèle Clément talks about an "epiphany of the name of the author in the sixteenth century" and emphasizes that the presence of the name on the title page was "increasingly frequent from 1520": "The author's name gradually appears in books between the end of the fifteenth and the end of the sixteenth century, building a new status for the author, who is increasingly identified 
s'autodésignent dans leurs vers. C'est ainsi que l'index des œuvres de Ronsard, par Alvin Emerson Creore, indique quatrevingt-onze occurrences du nom de Ronsard dans ses œuvres (Creore 1972 : 1196). Toutefois, les poètes s'entraident également pour se sauver collectivement de l'oubli : je suis poète "Pour honorer de renommee / Par le monde en mes vers semee / Mon nom et celuy des amis ${ }^{18}$ ", déclare Jean-Antoine de Baïf. Ainsi, alors que le recueil d'auteur prend le pas, vers le milieu du siècle, sur les recueils polygraphiques et les florilèges (Alduy $2007: 87-116$ ), la dimension collective demeure mais sous une autre forme : celle de la citation des « amis », et notamment des

amis poètes.

L'échange d'adresses entre poètes est alors un échange de bons procédés qui repose sur un transfert de crédits entre pairs (capital symbolique). En outre, cela permet à chacun de se montrer inséré dans un réseau. Par là même est valorisé un « capital social » entendu comme « ensemble des ressources actuelles ou potentielles qui sont liées à la possession d'un réseau durable de relations plus ou moins institutionnalisées d'interconnaissance et d'inter-reconnaissance ou, en d'autres termes, à l'appartenance à un groupe » (Bourdieu 1982 : 2). Cet échange implique les poètes dans un circuit de don et

dans les livres entre fin $\mathrm{XV}^{e}$ et fin $x \mathrm{Xl}^{\mathrm{e}}$ siècle, construisant un nouveau statut d'auteur, de plus en plus identifié à ce nom imprimé du créateur. Ce nouveau statut s'est créé par progressive dissociation sémantique entre auctor ou auctores (à savoir les " autorités [...]) et auteurs, autrices. Va donc émerger en langue vernaculaire une nouvelle catégorie sous ce mot puisqu'il n'est plus la seule traduction du latin auctores, renvoyant aux autorités classiques, mais forge un nouveau concept : les créateurs en langue vernaculaire " (Clément 2010 : 83-84). Précisons que le 27 juin 1551, l'édit de Châteaubriand contraint l'imprimeur à indiquer le nom d'auteur sur le livre.

18 Jean-Antoine de Baïf (2002). "A Monsieur Garraut tresorier de l'epargne (1573). œuvres complètes I, éd. J. Vignes (dir.). Paris, Champion : 423, v. 22-24. to guarantee their personal passage to posterity. Thus, the index of Ronsard's works by Alvin Emerson Creore indicates ninety-one occurrences of the name Ronsard in his works (Creore 1972: 1196). However, poets also help one another in order to save themselves collectively from oblivion: I am a poet "Pour honorer de renommee / Par le monde en mes vers semee / Mon nom et celuy des amis"20 (To honour with my reputation / Through the world by the verse I sow / My name and that of friends), declares Jean-Antoine de Baiif. Thus, when, towards the middle of the century, individual poets' collections start to prevail over collections by polygraphs and anthologies (Alduy 2007: 87-116), the collective dimension takes a new form: that of the citation of "friends," and in particular poet friends.

The exchange of addresses between poets is therefore a sharing of goodwill based on a transfer of credit between peers (symbolic capital). Moreover, each poet is thus seen to be part of a network, accentuating therefore their "social capital," which is "all the actual or potential resources linked to the possession of a lasting network of relations that are to varying degrees institutionalized by mutual knowledge and mutual recognition, or, in other words, to belonging to a group" (Bourdieu 1982: 2). This exchange involves poets in a pattern of gift exchange, similar to the mechanism exposed by Marcel Mauss in 1923-1924. For Mauss, the gift economy is based

with this printed name of the creator. This new status was created by progressive semantic dissociation between auctor or auctores (that is to say the 'autorités' [authorities]) and auteurs, autrices (authors, authoresses). A new category would therefore emerge under this word in the vernacular since it was no longer the only translation of the Latin auctores, referring to the classical authorities, but formed a new concept in the vernacular: creators" (Clément 2010: 83-84). It should be noted that on 27 June 1551 the Edict of Châteaubriand required printers to display the author's name on books.

20 Jean-Antoine de BAïF (2002). "A Monsieur Garraut tresorier de l'epargne" (1573). CEuvres complètes I. ed. J. Vignes. Paris, Champion: 423, v. 22-24. 
de contre-don, selon un mécanisme mis au jour par Marcel Mauss en 1923-1924, pour qui l'économie du don repose sur la force de la chose donnée et reçue - Mauss appelle cette force le « hau »poussant le donataire à rendre. Très vivace $a u x v l^{e}$ siècle, comme l'a montré Natalie Zemon Davis (2003), cette économie du don peut être étudiée dans le cadre du rapport des poètes à leurs mécènes (Skenazi 2003 ; Berriet 2009). Le poète offre un « bien symbolique " (poème, recueil) et le puissant offre un bien symbolique (soutien écrit, par exemple) ou matériel (pension, bénéfice), puisque l'autonomie économique de la littérature est loin d'être acquise à la Renaissance. Mais l'économie du don peut également être observée au sein du milieu des poètes qui s'échangent des marques de crédit.

Ce jeu des nominations croisées est donc l'angle par lequel nous avons voulu examiner l'histoire de la « Pléiade ». En rendant compte des réseaux de citations par le biais d'une base de données, il s'agit non pas de faire l'histoire des œuvres et de leurs affinités esthétiques mais l'histoire des relations affichées entre poètes pour observer entre qui s'échangent les marques de crédit ou les invectives, quel(s) collectif(s) se construi(sen)t, comment, contre qui, en vertu de quels dénominateurs communs. Ce faisant, ce sont les postures - au sens qu'a proposé Alain Viala de «présentation de soi » au public ou de « façon d'occuper une position » (Molinié \& Viala 1993 : 216) -, les représentations des relations amicales et conflictuelles entre pairs, ou encore les mises en scène du poète en groupe qui nous intéressent.

« RéseauxPoètesXVI » : constitution d'une base de données et mise en réseau de 280 noms

Pour constituer notre corpus, nous avons consulté de nombreux recueils imprimés. Cette lecture sélective consistait à repérer dans les ouvrages : on the power of the thing given and received - this power is called "hau," and pushes the recipient to reciprocate. Very much alive in the sixteenth century, as Natalie Zemon Davis (2000) has shown, this gift economy can be studied in the context of the relationship of poets to their patrons (Skenazi 2003; Berriet 2009). The poet gives a "symbolic good" (a poem or collection) and the patron a symbolic (written support, for example) or material good (an allowance or benefit), since the economic autonomy of literature is far from assured in the Renaissance. But the gift economy can also be observed within the milieu of poets who exchange symbols of credit.

And so this game of cross references is the angle through which we want to examine the history of the "Pléiade." By recording networks of citations using a database, the endeavour entailed - rather than a history of works and their aesthetic affinities - building a history of relationships displayed between poets to observe between whom symbols of credit or insults are exchanged, which groups are formed, how, against whom, and with which common denominators. I am therefore interested in the "postures" - in the sense of "selfpresentation" to the public as proposed by Alain Viala, or as a "way of holding a position" (Molinié \& Viala 1993: 216) -, and in the representations of friendly or conflicting relationships between peers, or of the poet in a group.

\section{"RéseauxPoètesXVI": Composing the Database and Establishing a Network of 280 Names}

To build my corpus, I consulted many published collections. The aim of this selective reading was to locate in the works: 
- Les pièces dans lesquelles l'auteur du recueil nomme des confrères (préfaces, "Aux lecteurs », poèmes du recueil qui s'adressent à un pair, construisent une certaine vision de l'histoire littéraire, dressent des listes de « bons ${ }^{19}$ ", invectivent un confrère, racontent une scène de sociabilité poétique, etc.) - Les pièces allographes qui sont écrites par un pair et intégrées par l'auteur à son recueil. En effet, Cécile Alduy l'a souligné : pour les poètes de la seconde moitié du $x \mathrm{~V}^{\mathrm{e}}$ siècle, le livre a une « fonction de lieu socialisé destiné à accueillir d'autres poètes, voire d'autres langues, et témoigne de la distance historique qui le sépare de notre conception de l'unité indissociable livre-œuvres-écrivains » (2007 : 260). Jean Vignes considère que ces textes offrent « de précieux indices pour reconstituer les réseaux d'influence et d'amitiés qui forment la trame de la vie humaine » (2004:183) et en propose une typologie. II distingue, d'une part, les allographes liminaires et postliminaires, c'est-à-dire les cautions des pairs qui font du péritexte, selon Daniel Maira, l'« espace d'une approbation collective » (2007 : 267), et ce depuis les années 1530 (Laufer 1989 [1982] : 583). Des phénomènes de « parrainage social et littéraire » (Alduy 2007 : 344) s'y observent, qu'un auteur réputé offre à un débutant un liminaire élogieux ou qu'un auteur réputé accepte d'accueillir au seuil de son livre le poème d'un débutant qui chante ses louanges. Jean Vignes distingue, d'autre part, les allographes parenthétiques, c'està-dire « un texte de $\mathrm{A}$ intercalé au sein du volume, parmi les pièces de l'auteur principal » (2004 : 181). Cela permet de mettre en scène des débats à coup d'adresses, de réponses et de contre-réponses sous la forme de dizains, de sonnets ou d'épîtres le plus souvent.

Pour faire le relevé de ces pièces de contact, nous avons commencé par lire les recueils des poètes dits de la «Pléiade ». Pour la plupart, leurs œuvres complètes connaissent des éditions modernes et

19 Nous les appellerons « poèmes-listes ».
- pieces in which the author of the collection names peers (prefaces, "Notes to the Reader," and poems in the collection which address a peer, construct a certain vision of literary history, draw up lists of fine poets, ${ }^{21}$ curse a colleague, recount a scene of poetic sociability, etc.);

- allographic pieces written by a peer and incorporated into the collection by its author. Indeed, Cécile Alduy stresses that, for poets in the second half of the sixteenth century, books serve as "a socialized space intended to accommodate other poets, even other languages, and reflects the historical distance that separates it from our conception of the inseparable unity of book-works-writers" (2007: 260). Jean Vignes believes these texts offer "precious clues for rebuilding networks of influence and friendship that form the basis of human life" (2004: 183), and proposes a typology. He makes a distinction between, on the one hand, liminary/postliminary allographs which are endorsements from peers and make, according to Daniel Maira, the peritext into a "space of collective approval" (2007: 267), dating from the 1530s (Laufer 1989 [1982]: 583). "Social and literary patronage" phenomena (Alduy 2007: 344) can be observed here, when a respected writer provides a eulogistic liminary text to someone starting out in their career, or agrees to having a poem by an unknown poet sings their praises at the start of the book. Jean Vignes then distinguishes parenthetic allographs, on the other hand: "a text by A inserted into a volume, among the work of the main writer" (2004: 181). This is a way of presenting debates by means of addresses, responses, and counter-responses in the form of dizains, sonnets or, most often, epistles.

To map references, I began by reading collections by poets of the so-called "Pléiade." For the most part, their complete works are available in modern editions and some have been digitized

21 We call these "list-poems." 
quelques-unes sont numérisées (sur archive.org ou dans la collection des classiques Garnier numériques, par exemple). Certains de ces poètes, comme nous l'avons vu, ont une longue carrière qui se poursuit jusqu'aux années 1580. À partir des noms de poètes qu'ils citent ou qui signent des textes qu'ils intègrent à leurs recueils, nous avons étendu nos lectures. De rebond en rebond, nous avons dépouillé 312 recueils répartis sur la période 1549-1586, ce qui permet d'observer les interactions entre poètes sur deux générations poétiques, à savoir celle qui fait ses débuts dans les années 1550 - et dont quelques acteurs publient jusque dans les années 1580 (génération 1550 dans la suite du texte) et celle qui fait ses débuts dans les années 1570 (génération 1570 dans la suite du texte) : -1549-1569 (20 ans) : 184 recueils consultés ; -1570-1586 (16 ans) : 128 recueils consultés.

Bon nombre de ces recueils de poètes moins connus de nos jours ne connaissent pas d'édition moderne et ont été consultés dans l'édition originale du $x \mathrm{vl}$ e siècle grâce à des bibliothèques numériques (Gallica et les Bibliothèques Virtuelles Humanistes, notamment) ou grâce au service en ligne Google Books. Ces ressources épargnent néanmoins rarement le travail de saisie des textes. C'est ainsi que, au fur et à mesure des lectures, nous avons saisi en traitement de texte des centaines de pièces. La Renaissance avait inventé la " roue à livres », un outil permettant de lire plusieurs livres à la fois. Les ouvrages étaient disposés sur des plateaux auxquels on pouvait accéder en faisant tourner la roue afin de comparer les passages sélectionnés. II nous fallait une « roue à livres » moderne pour mettre les textes relevés en lien les uns avec les autres. En vertu de notre double objectif, qui était de rendre compte d'un réseau mais aussi d'analyser des postures, nous avons choisi de réaliser une base de données qui renseigne à la fois des données relationnelles (dans tel texte, publié dans tel recueil, à telle date, tel poète s'adresse à/évoque tel.s poète.s) et donne accès aux textes pour autoriser des analyses qualitatives. (on archive.org or in the Garnier digital collections of classics, for example). Some of these poets, as we have seen, had long careers that lasted until the 1580s. I extended my reading beyond the names of poets they cite or those who signed texts that were incorporated into their collections. Moving from one to another, I thus scrutinized 312 collections spanning the period 1549-1586; I was then able to observe interactions between poets from two generations: those who made their début in the 1550s (or "the 1550 generation" hereafter) - of whom some published until the 1580s; and those who made their début in the 1570s (or "the 1570 generation" hereafter):

-1549-1569 (20 years): 184 collections consulted;

-1570-1586 (16 years): 128 collections consulted.

Many of the poets' collections that are less well-known today have no modern edition and were consulted in their original sixteenth-century edition thanks to digital libraries (Gallica and the Bibliothèques Virtuelles Humanistes, in particular) or the Google Books online service. However, these resources rarely spared me the work of inputting the texts. In this way, my reading gradually resulted in hundreds of word-processed pieces. The "book wheel" was invented in the Renaissance, a tool which allowed several books to be read at once. Works were placed on shelves which could be accessed by turning the wheel to compare the selected passages. I needed a modern "bookwheel" to link the collected texts to one another. According to this double objective, which was to come up with evidence of a network but also to analyse postures, I chose to create a database to provide both relational data (in this text, published in this collection, on this date, this poet addresses/ mentions this [these] poet[s]) and give access to texts to enable qualitative analysis. 
Figure 2. Organisation des données dans "RéseauxPoètesXVI "

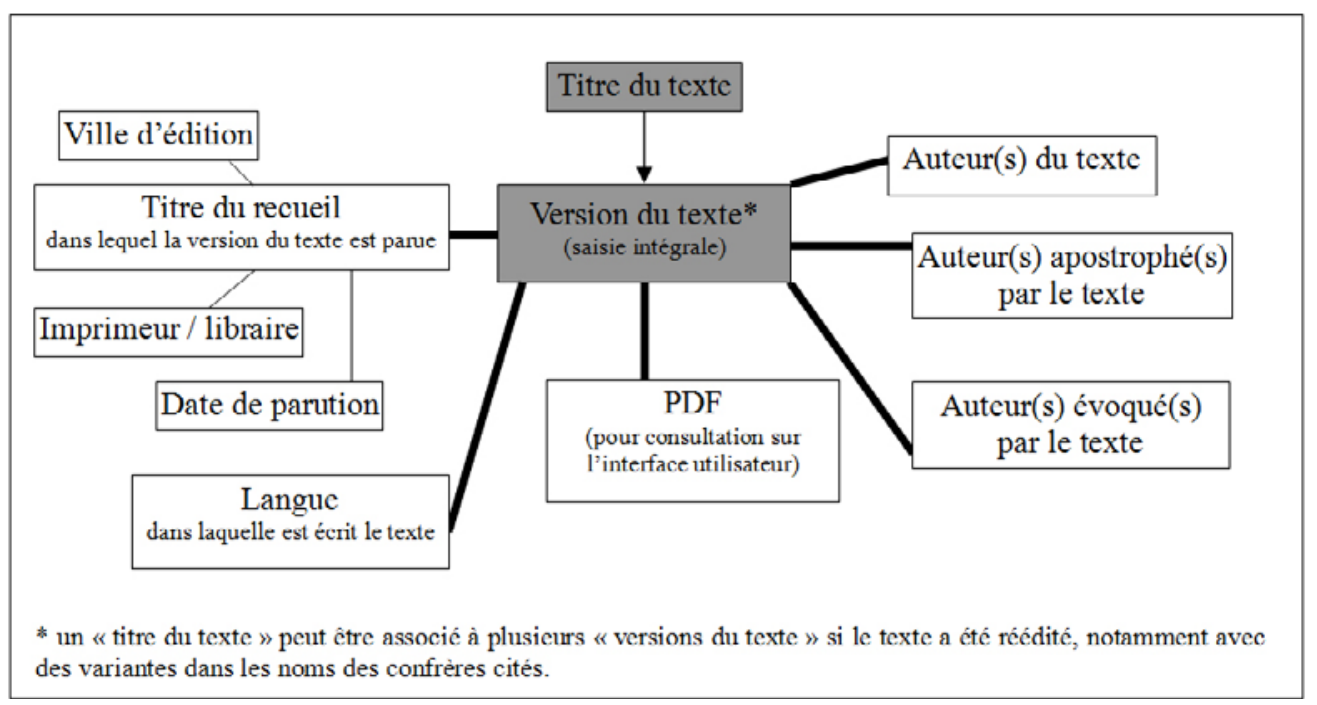

Figure 2. Data organization in the des variantes dans les noms des confrères cités. database "RéseauxPoètesXVl"

Si la décision de saisir en intégralité les textes a entraîné un volume horaire de travail très conséquent ${ }^{20}$, elle s'est avérée judicieuse dans la mesure où des besoins sont apparus, au fur et à mesure de la progression de notre réflexion, qui n'avaient pas été anticipés. Les recherches plein texte, qu'autorise la saisie intégrale des pièces du corpus, peuvent ainsi suppléer aux tables qui manquent dans la conception d'ensemble de la base de données.

Celle-ci, programmée en PHP, a été réalisée bénévolement par des amis informaticiens avec le système de gestion de base de données relationnelle MySQL. Elle est hébergée sur le serveur de

I'Université Lyon 2. Les données sont organisées comme suit :

Dans le cadre limité de cet article, nous ne développerons pas combien l'enregistrement de certaines données du livre (lieu d'édition, identité de l'imprimeur-libraire) a son importance pour

20 Nous avons travaillé seule à la réalisation de cette base de données, en dehors de tout projet collaboratif de laboratoire.

While the decision to enter the full texts led to a very considerable volume of work, ${ }^{22}$ it proved judicious inasmuch as previously unforeseen needs emerged as my reflection progressed. Fulltext searches, which allowed complete data entry for works in the corpus, could thus supplement the tables missing from the design of the overall database.

The database, which uses PHP, was built pro bono by programmer friends using the MySQL relational database management system. It is hosted on the server of the University of Lyon 2. The data are organized as follows:

Given the limited framework of this article, I will not detail how significant the recording of certain book data (place of publishing, identity of printer-bookseller) was in accounting for the role of these

22 I worked on developing this database alone, and not as part of any collaborative project. 
prendre en compte le rôle des professionnels du livre dans la construction des réseaux de poètes. Nous nous restreindrons ici à quelques analyses des réseaux de citations entre auteurs.

De fil en aiguille, ce sont 2200 textes que nous avons intégrés dans la base "RéseauxPoètesXVI ». Ils sont issus des 312 recueils dépouillés qui émanent de 60 auteurs différents. Toutefois, par le biais des adresses à des pairs et des pièces allographes, ce sont 280 noms d'hommes et de femmes qui sont insérés dans un réseau dont la base de données rend compte.

L'interface utilisateur, accessible à tous, propose plusieurs requêtes :

- Des recherches de textes : par nom d'auteur, par titre de texte, par titre de recueil, par date de publication, par langue d'écriture (français, latin, grec, italien, espagnol), par éditeur et par recherche plein texte

- Des recherches de rapports entre auteurs permettant d'aboutir à des textes : par exemple, en demandant tous les textes de tel auteur citant tel.s auteur.s pendant toute sa carrière ou à une date précise ou sur une période historique déterminée, ou bien en demandant la liste de tous les auteurs auquel untel s'est adressé pendant toute sa carrière ou à une date précise ou sur une période historique déterminée, etc. Les résultats s'affichent sous forme de listes de textes que l'on peut consulter :

- Des recherches de rapports entre auteurs permettant d'aboutir à des résultats chiffrés : par exemple, en faisant une requête sur tous les auteurs qui citent tel auteur. Les résultats s'affichent sous forme de tableaux et de diagrammes. book professionals in the construction of the networks of poets. I will limit my analysis to the study of the networks of citations between poets.

Little by little, lincorporated 2,200 texts into the "RéseauxPoètesXVI" database. These came from the 312 collections that I scrutinized by sixty different poets. However, when taking addresses to peers and allographic pieces into account, 280 names of men and women were integrated into the network which was rendered by the database.

The user interface, accessible to all, proposes several inquiries:

- Text searches: by name of poet; text title; collection title; date; publication; language (French, Latin, Greek, Italian, Spanish); publisher; or by full text search.

- Searches by relationships between poets, with results given as a list of texts: for example, it is possible to request all the texts by this poet citing this/these other poet(s) either throughout his/her career, or on a specific date, or during a specified historical period; or it is possible to request the list of all the poets this author addresses either throughout his/her career, or on a specific date, or during a specified historical period, etc. The results are displayed in the form of a list of texts which can be consulted.

- Searches by relationships between poets, with results given as numbers: for example, it is possible to search for all the authors who cite this poet. Then, results are displayed in the form of tables and diagrams. 


\section{Apport de la base pour l'histoire littéraire}

La Pléiade : un imaginaire groupal parmi d'autres

La mise en série de 2200 pièces de contact, sur une période longue de presque quarante ans, permet d'insérer les quelques mentions de la Pléiade (par Ronsard, par quelques-uns de ses adversaires réformés au début des années 1560, et par quelques poètes de la génération suivante) et les quelques références à une Brigade de bons poètes (par Ronsard et quelques-uns de ses amis dans les années 1550-1560 : Baïf, Magny, Belleau, Grévin) dans un ensemble vaste de textes valorisant de diverses manières des sociabilités littéraires choisies.

En embrassant large, ce qui n'aurait pas été possible sans l'outil informatique, nous pouvons articuler de multiples conceptions du collectif, qu'elles reposent sur un critère géographique (représentations du réseau poitevin, liste des bons poètes de la Gascogne, etc.), sur un critère d'âge (conflits de " générations "), sur un critère esthétique (poètes inspirés contre petits rimeurs, poètes qui chantent Dieu contre poètes qui chantent l'amour), sur un critère confessionnel (poètes catholiques, poètes protestants) ou encore sur un critère sexué (les femmes, qui ont toutefois des difficultés à faire réseau).

La base de données permet aisément de repérer tous les textes qui mobilisent par exemple les qualificatifs « jeune » ou « vieux » pour observer les phénomènes générationnels. L'ancrage géographique, lui, peut s'approcher par la requête « lieu d'édition » ou par une recherche plein texte sur les noms de régions, de cours d'eau et de villes nommées. Une recherche sur «Paris » (comme lieu d'édition et comme mot présent dans les textes) permet d'observer la construction du mythe de la ville de Paris comme centre du monde, depuis l'éloge ronsardien de « la ville où sont infuses / La discipline,

\section{The Database's Contribution to Literary History}

\section{The Pléiade: An Imaginary Group Among Others}

The integration of 2,200 references over a long period of almost forty years made it possible to incorporate the few mentions of the Pléiade (by Ronsard, by some of his Protestant adversaries at the start of the 1560s, and by some poets of the following generation) and the few references to a Brigade of fine poets (by Ronsard and some of his friends in the 1550s and 1560s: Baif, Magny, Belleau, and Grévin) in a whole range of texts highlighting chosen forms of literary sociability in various ways.

Such a wide reach, which would not have been possible without a data-processing tool, meant I could link multiple types of group, whether based on: geographic criteria (representations of the Poitevin network, a list of esteemed poets from Gascony, etc.); age ("generational" conflicts); aesthetic criteria (visionary poets versus simple rhymers, poets who sing about God versus poets who sing about love); denominational criteria (Catholic poets, Protestant poets); or even gendered criteria (women, though they had difficulties establishing a network).

The database allowed easy identification of all texts which used, for example, the qualifiers "young" or "old" to observe generational phenomena. As for the geographical anchor, this could be accessed viaa search for "place of publication" or by a full-text search for regions, rivers, or towns named. A search for "Paris" (as place of publication and as a word present in the texts) reveals the construction of the myth of the city of Paris as the centre of the world, from Ronsard's praise 
\& la gloire des Muses ${ }^{21}$ » (1550) jusqu'à l'exaltation de « Paris, mere des artz, des peuples, \& des villes, / Des richesses, des loys, \& polices civilles ${ }^{22}$ » par Jean de La Gessée (1583), en passant par l'affirmation

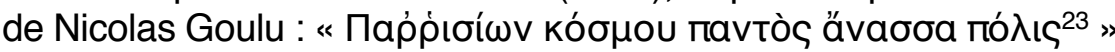
(1578), soit « la cité des Parisiens est maîtresse de toute la terre ». Les poètes dits de la «Pléiade » participent activement de cette valorisation de Paris en imprimant leurs œuvres à Paris, en datant leurs « Aux lecteurs » de « Paris, ce... » et en chantant les louanges de la ville dans leurs vers. Dans le même temps, plusieurs cercles d'excellence provinciaux sont particulièrement valorisés dans les textes que nous avons recensés

- Des réseaux poitevins, manceaux et normands : des poèmeslistes ${ }^{24}$, des tombeau ${ }^{25}$, des échanges de poètes à poètes faisant état d'un même attachement à un territoire ${ }^{26}$, révèlent des réseaux

21 Pierre de Ronsard (1914). "A son retour de Gascongne ». CEuvres complètes II. Paris, Hachette : 199, v. 2-3.

22 Jean de La Gessée (1583). «L'ombre du Roy Françoys I. Au Roy Henry III. Discours VI », Les Premieres oeuvres françoyses de Jean de la Jessée, Secretaire de la Chambre de Monseigneur, Tome troisieme. Anvers, Christophe Plantin (exemplaire de la BnF, Rés. Ye-487) : 1423, v. 157-158.

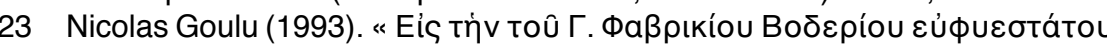

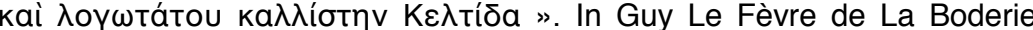
La Galliade, éd. F. Roudaut. Paris, Klincksieck : 123. La traduction est celle donnée par François Roudaut.

24 Par exemple "Aux Muses les convïant en son païs du Maine » de Jacques Tahureau du Mans dans Les Premieres Poësies de 1554 paru chez les frères Marnef et Bouchet à Poitiers. Tahureau valorise un « brave troupeau savant » (v. 51) composé d'une dizaine de serviteurs des Muses qui font du Maine « un autre Parnasse » (v. 6). Jacques Tahureau (1984), éd. T. Peach. Genève, Droz : 218-223.

25 La Médée, Tragédie. Et autres diverses Poesies, par feu J. de La Peruse. Poitiers, de Marnefz \& Bouchetz freres, 1556.

26 Par exemple, plusieurs pièces des Foresteries de Jean Vauquelin de La Fresnaye parues en 1555 chez les frères Marnef et Bouchet à Poitiers, et adressées à des poètes du Poitou, du Maine et de la Normandie. Jean of "la ville où sont infuses / La discipline, \& la gloire des Muses"23 (the city where are found / Discipline, and the glory of the Muses) (1550) until the exaltation of "Paris, mere des artz, des peuples, \& des villes, / Des richesses, des loys, \& polices civilles"24 (Paris, mother of the arts, people, and cities, / Riches, laws, and civil policy) by Jean de La Gessée (1583), via Nicolas Goulu's affirmation: "Пaṕṕóíwv

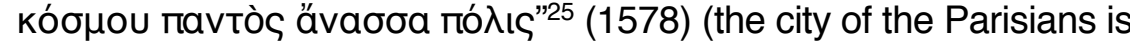
mistress of the whole earth). The so-called "Pléiade" poets played an active part in this promotion of Paris, printing their works there, dating their "Notes to the Reader" as being from Paris, and singing the praises of the city in their verse. At the same time, several provincial circles of excellence are extolled in the examined texts:

- Networks from Normandie, Poitou, and Le Mans region: some list-poems, ${ }^{26}$ tombeaux poétiques, ${ }^{27}$ exchanges between poets demonstrating a similar attachment to a place,${ }^{28}$ reveal networks

23 Pierre de Ronsard (1914). "A son retour de Gascongne." In CEuvres complètes II. Paris, Hachette: 199, v. 2-3.

24 Jean de La Gessée (1583). "L’ombre du Roy Françoys I. Au Roy Henry III. Discours VI." Les Premieres oeuvres françoyses de Jean de la Jessée, Secretaire de la Chambre de Monseigneur, Tome troisieme. Anvers, Christophe Plantin (copy of the Bibliothèque nationale de France [BnF], Rés. Ye-487): 1423, v. 157-158

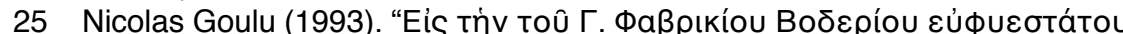

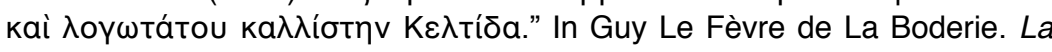
Galliade, ed. F. Roudaut. Paris, Klincksieck: 123.

26 For example, "Aux Muses les convïant en son païs du Maine" by Jacques Tahureau from Le Mans in Les premieres poësies of 1554 was published by the Marnef and Bouchet brothers in Poitiers. Tahureau highlights a "brave troupeau savant" (brave learned flock) (v. 51) comprising ten or so servants of the Muses, who made Le Mans into "un autre Parnasse" (another Parnassus) (v. 6). Jacques Tahureau (1984). ed. T. Peach. Geneva, Droz: 218-223.

27 La Médée, Tragédie. Et autres diverses Poesies, par feu J. de La Peruse. Poitiers, de Marnefz \& Bouchetz frères, 1556.

28 For example, several poems from Foresteries by Jean Vauquelin de La Fresnaye published in 1555 by the Marnef and Bouchet brothers in Poitiers 
poitevins et manceaux notamment dans les années 1550, avec des fluctuations dans la composition des groupes au fil des ans; dans les années 1570, on retrouve quelques-uns des membres de ce réseau (Charles Toutain, par exemple) dans des recueils qui révèlent une intense activité lettrée en Normandie $^{27}$;

- Des réseaux quercinois et gascons : des poèmes-listes ${ }^{28}$ esquissent les contours d'une émulation poétique toulousaine dans les années 1550 ; puis, dans les années 1570, plusieurs recueils ${ }^{29}$ et quelques échanges de poètes à poètes ${ }^{30}$ témoignent de la vivacité

Vauquelin de la Fresnaye (1956). Les Foresteries, éd. M. Bensimon. Genève/ Lille, Droz/Girard : 37-51.

27 Diverses meslanges poetiques. Par Guy Le Fevre de la Boderie, Paris, Robert le Mangier, 1578. La Galliade ou de la Révolution des arts et des sciences. [...] Par Guy le Févre de la Boderie, Paris, Guillaume Chaudière, 1578.

28 Par exemple, dans des pièces d'Olivier de Magny comme «A François Revergat. Ode » (1553) ou " A Monsieur d'Avanson, premier President au grand conseil du Roy, en faveur de Pierre de Paschal. Ode de la Justice " (1559). Olivier de Magny (1999). CEuvres poétiques I, éd. F. Rouget. Paris, Champion : 246-249 ; Id. (2006). CEuvres poétiques II, éd. F. Rouget. Paris Champion : 207-211.

29 La Muse Chrestien de $G$. de Saluste seigneur Du Bartas (Bordeaux, Simon Millanges, 1574) n'interpelle que des lettrés gascons. Le recueil des Poemes de Pierre de Brach Boudelois (Bordeaux, Simon Millanges, 1576) est soutenu par des liminaires exclusivement signés par des Bordelais. Brach s'y adresse principalement à des lettrés de Bordeaux ou des environs et développe un discours de promotion de Bordeaux qui s'adresse souvent à Ronsard (par exemple, « Hymne de Bourdeaux, à monsieur de Ronssart »). Gérard-Marie Imbert dans son recueil de 1578 intitulé Premiere partie des sonets exoteriques, paru lui aussi à Bordeaux chez Millanges, s'adresse également à de nombreux gascons. Certains noms se retrouvent dans ces trois recueils qui offrent toutefois aussi chacun des variantes, de sorte que les réseaux qui y sont promus ne sont pas exactement les mêmes.

30 Par exemple, François de Belleforest (1573). « Sonnet » liminaire offert à Jean de La Gessée pour La Rochelleide. Paris, Gilles Blaise, exemplaire de la BnF, YE-55606. Le titre du sonnet insiste sur les ancrages géographiques : « Sonet de François de Belleforest Comingeois sur la Rochelleide de J. la Gessée Gascon Mauvesinois ». from Poitou and Le Mans region in particular during the 1550s, with fluctuations in the composition of groups over the years; in the 1570s, some members of this network (Charles Toutain, for example) can be found in collections which reveal intense learned cultural activity in Normandy. ${ }^{29}$

- Networks from Quercy and Gascony: some list-poems ${ }^{30}$ sketch the outline of a poetic emulation in Toulouse in the 1550s; then, in the 1570 s, several collections ${ }^{31}$ and exchanges between poets ${ }^{32}$

and addressed to poets of Poitou, Le Mans, and Normandy. Jean Vauquelin de la Fresnaye (1956). Les Foresteries, ed. M. Bensimon. Geneva/Lille, Droz/ Girard: 37-51.

29 Diverses meslanges poetiques. Par Guy Le Fevre de la Boderie, Paris, Robert le Mangier, 1578. La Galliade ou de la Révolution des arts et des sciences. ... Par Guy le Févre de la Boderie, Paris, Guillaume Chaudière, 1578.

30 For example, in poems by Olivier de Magny such as "A François Revergat. Ode" (1553) or "A Monsieur d'Avanson, premier President au grand conseil du Roy, en faveur de Pierre de Paschal. Ode de la Justice" (1559). Olivier de Magny (1999). CEuvres poétiques I, ed. F. Rouget. Paris, Champion: 246-249 Id. (2006). CEuvres poétiques II, ed. F. Rouget. Paris, Champion: 207-211.

31 La Muse Chrestien de G. de Saluste seigneur Du Bartas (Bordeaux, Simon Millanges, 1574) only hails literate Gascon readers. The Poemes de Pierre de Brach Boudelois (Bordeaux, Simon Millanges, 1576) collection includes liminary texts exclusively by poets from Bordeaux. Among them, Brach primarily addresses the literate circles of Bordeaux or surroundings, and develops a discourse promoting Bordeaux which often addresses Ronsard (for example, "Hymne de Bourdeaux, à monsieur de Ronssart"). Gérard-Marie Imbert in his 1578 collection titled Premiere partie des sonets exoteriques, also published in Bordeaux by Millanges, similarly addresses many Gascons. Some names figure in each of these three collections, which offer however some variants so much so that the networks that they highlight, are never exactly the same.

32 For example, François de Belleforest (1573). liminary "Sonnet" given to Jean de La Gessée for La Rochelleide. BnF copy, YE-55606. Paris, Gilles Blaise. The title of the sonnet emphasizes its geographic roots: "Sonet de François de Belleforest Comingeois sur la Rochelleide de J. la Gessée Gascon Mauvesinois". 
de cercles lettrés gascons et de l'attachement des Gascons à leur terre natale ;

- Les réseaux lyonnais et mâconnais : autour de Maurice Scève, Guillaume Des Autels et Pontus de Tyard, une émulation poétique lyonnaise et mâconnaise se donne à lire dans les années 1550 , que ce soit par le biais des adresses de poètes à poètes ${ }^{31}$, des couronnes encomiastiques ${ }^{32}$, ou des poèmes-listes ${ }^{33}$

Des études de détail permettent ensuite d'analyser de manière plus précise le positionnement de tel ou tel poète dont l'ancrage en province est fort. Nous pouvons, par exemple, demander la liste des poètes interpellés ou évoqués par Jean Bastier de La Péruse avec une indication de fréquence.

On voit alors que Bastier de La Péruse interpelle principalement des poètes qui vivent ou séjournent dans la même région que lui, le Poitou : il s'adresse trois fois à Jacques Tahureau (16,7 \% des

31 Par exemple, le premier sonnet des Erreurs amoureuses de Pontus de Tyard, parues en 1549 à Lyon chez Jean de Tournes, est adressé à Maurice Scève. Autre exemple, le premier poète que cite Guillaume Des Autels dans le Repos de plus grand travail, paru à Lyon en 1550 chez Jean de Tournes, est Maurice Scève. Entre eux, Tyard et Des Autels s'interpellent fréquemment dans leurs recueils poétiques des années 1550.

32 Voir, par exemple, les «Escriz de divers poètes, à la louenge de Louize Labé lionnoize » dans les Euvres de Louïze Labé Lionnoize (Lyon, Jean de Tournes, 1555), éd. F. Rigolot. Paris, Gallimard, 2004. L'expression " couronne encomiastique » est empruntée à Cécile Alduy (2007) dans Politique des «Amours ». Poétique et genèse d'un genre français nouveau (1544-1560). Forgée sur le substantif « encomiaste » (personne qui rédige un éloge), l'expression désigne les poèmes de louanges à la gloire de l'auteur qui se trouvent dans le paratexte à l'ouverture et à la clôture du livre.

33 Par exemple, Philibert Bugnyon (1998). «Chant panegyric » (1557), Erotasmes de Phidie et Gelasine, éd. G.-A. Pérouse et M.-O. Sauvajon. Genève, Droz : 192-205. testify to the vivacity of literary circles in Gascony and to the attachment of the Gascon people to their native land.

- Networks from the Lyon and Mâcon regions: poetic emulation around Maurice Scève, Guillaume Des Autels and Pontus de Tyard flourished there in the 1550s, either via poets addressing one another, ${ }^{33}$ or via encomiastic honours, ${ }^{34}$ or list-poems. ${ }^{35}$

With detailed study, it is possible to analyse more precisely how the poets with strong ties to a province are positioned in other networks. One can, for example, ask for a list of poets addressed or mentioned by Jean Bastier de La Péruse with an indication of frequency.

One therefore can see that Bastier de La Péruse primarily names poets living or staying in the same region as him, Poitou: he addresses Jacques Tahureau three times (16.7\% of La Péruse's

33 For example, the first sonnet in Pontus de Tyard's Erreurs amoureuses, published in 1549 in Lyon by Jean de Tournes, is addressed to Maurice Scève. In another example, the first poet cited by Guillaume Des Autels in Repos de plus grand travail, published in Lyon in 1550 by Jean de Tournes, is Maurice Scève. Tyard and Des Autels frequently name each other in their poetry collections of the 1550s.

34 See, for example, "Escriz de divers poètes, à la louenge de Louize Labé lionnoize" in Euvres de Louïze Labé Lionnoize (Lyon, Jean de Tournes, 1555), ed. F. Rigolot, Paris, Gallimard, 2004. The expression couronne encomiastique (encomiastic honour) is borrowed from Cécile Alduy (2007) in Politique des "Amours." Poétique et genèse $d \square u n$ genre français nouveau (1544-1560). Based on the noun "encomiast" (someone who praises another in writing), the expression refers to poems that praise the glory of the poet and can be found in the paratext opening and closing a book.

35 For example, Philibert Bugnyon (1998). "Chant panegyric," (1557) Erotasmes de Phidie et Gelasine, ed. G.-A. Pérouse and M.-O. Sauvajon. Geneva, Droz: 192-205. 
adresses à un poète chez La Péruse), et deux fois à Jean-Antoine de Baif, Jean Boiceau de La Borderie et Roger Maisonnier (11,1\% chacun). En revanche, il évoque principalement des poètes qui ont acquis une bonne notoriété à la cour et hantent les milieux parisiens : il évoque cinq fois Ronsard, quatre fois Du Bellay et quatre fois Baif. Ce dernier fait office de figure intermédiaire entre les poètes parisiens - pour avoir promu lui aussi la Brigade et avoir partagé avec elle l'élan enthousiaste du début des années 1550 - et le groupe poitevin - pour avoir séjourné à Poitiers pendant l'année universitaire 1553-1554. De la sorte, il apparaît qu'un lien de fréquentation se matérialiserait préférentiellement sous la plume de Bastier de La Péruse par une adresse directe tandis qu'un lien de connaissance (par ouï-dire ou par lecture) se matérialiserait préférentiellement par une évocation. addresses to a poet), and Jean-Antoine de Baïf, Jean Boiceau de La Borderie, and Roger Maisonnier twice (11,1\% each). On the other hand, he primarily alludes to poets who have gained a good reputation at court and who frequent the Parisian milieux: he alludes to Ronsard five times, and four times each to Du Bellay and Baïf. The latter acted as an intermediary figure between the Parisian poets - since he had also been promoted to the Brigade and since he shared in their enthusiastic impetus at the start of the 1550s and the Poitevin group - having stayed in Poitiers for a year of his university studies 1553-1554. In this way, it would appear that links of regular contact occur in Bastier de La Péruse's writing via direct address, while links of acquaintance (through hearsay or reading) were made most often by means of allusion.

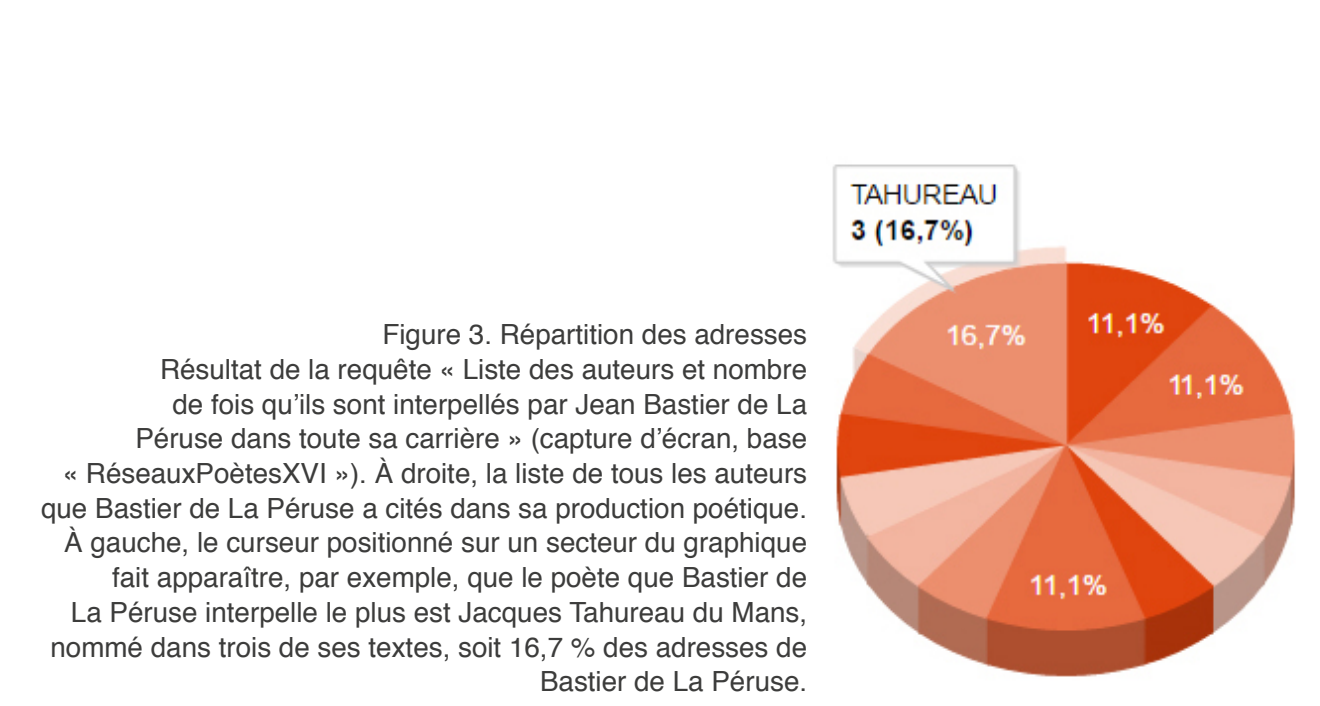

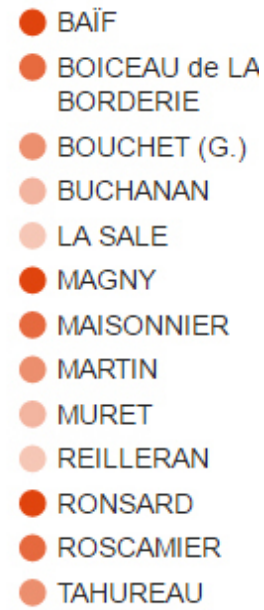

D'autres critères que la proximité géographique peuvent présider à la mise en scène d'un regroupement de noms d'auteurs, par exemple un numerus clausus symbolique. Dans ce cadre-là, le
Other criteria apart from geographic may determine the presentation of a grouping of poets, such as, for example, a symbolic numerus clausus. In this respect, the seven of the Pléiade is not the only 
sept de la Pléiade n'est pas le seul chiffre qui stimule l'imaginaire des poètes. Une requête proposée dans l'interface utilisateur de «RéseauxPoètesXVI » permet de sélectionner les textes qui citent un nombre déterminé de noms. La lecture des poèmes par ce prisme-là entraîne quelques découvertes. Ainsi, quand Ronsard (1556) pense à la Pléiade des sept filles d'Atlas et Pléioné qui ont donné leur nom à une constellation et à un groupe de poètes alexandrins du $\mathrm{III}^{\mathrm{e}}$ siècle avant J.-C., Philibert Bugnyon (1557) ${ }^{34}$ et Gérard-Marie Imbert $(1578)^{35}$ pensent au chiffre des Muses pour établir des listes de neuf bons poètes - comme l'avait fait avant eux Charles de Sainte-Marthe dans le «Tempé de France » (1540) -, et d'autres, comme Baïf

$(1574)^{36}$, cherchent à désigner douze apôtres de la poésie.

L'idée d'une Pléiade de bons poètes ne séduit d'ailleurs pas que Ronsard. Une vingtaine d'années après le Vendômois, Pascal Robin Du Faux, en 1579, évoque une «Pleiade Angevine » dont l'étoile la plus brillante serait Pierre Le Loyer ${ }^{37}$. Sans doute pense-t-il à la Pléiade ronsardienne et veut-il la réactualiser en un lieu spécifique (l'Anjou) et avec d'autres membres. Car si aucun des poètes qui auraient pu se réclamer de la Pléiade de Ronsard (Remy Belleau, Joachim Du Bellay, Jean-Antoine de Baïf, etc.) n'a revendiqué son appartenance à un tel groupe, cet imaginaire ronsardien a tout de même fortement marqué quelques-uns de ses contemporains.

34 Philibert Bugnyon (1998). «A Monsieur Neri de Torveon [ ]. Sonnet I » (1557) Erotasmes de Phidie et Gelasine, éd. G.-A. Perouse et M.-O. Sauvajon. Paris-Genève, Droz : 9-10.

35 Gérard-Marie Imbert (1872). Sonnet 5 « Sauf ta paix et ta grace, » (1578). Première partie des Sonnets exotériques de Gérard Marie Imbert, éd. Ph. Tamizey de Larroque. Paris/Bordeaux, A. Claudin/G. Gounouilhou : 42.

36 Jean-Antoine de Baïf (1966). «Aus poêtes fransoês » dans Euvres en rime, t. V, éd. Ch. Marty-Laveaux. Slatkine Reprints : 323-324.

37 Pascal Robin Du Faux (1579). « Du mesme. Stanze ». Les CEuvres et meslanges poetiques de Pierre Le Loyer Angevin. Paris, Jean Poupy (BnF, Rés. p-Ye-146). figure that captures poets' imagination. One search proposed by the "RéseauxPoètesXVI" user interface allows selection of texts which cite a given number of names. Reading poems through such a prism leads to several discoveries. Thus, while Ronsard (1556) thinks of the Pléiade of the seven daughters of Atlas and Pleione, whom a constellation and a group of third-century BC Alexandrine poets were named after, Philibert Bugnyon (1557) ${ }^{36}$ and GérardMarie Imbert (1578) ${ }^{37}$ think of the figure of the Muses to establish lists of nine fine poets - as Charles de Sainte-Marthe had done before them in the "Tempé de France" (1540) - and others, such as Baïf (1574), ${ }^{38}$ look to designate Twelve Apostles of poetry.

Ronsard, moreover, isn't the only one to be seduced by the idea of a Pléiade of fine poets. Twenty years after him, Pascal Robin Du Faux alludes to a "Pléiade Angevine" (a Pléiade from the Anjou region) in 1579, whose most brilliant star would be Pierre Le Loyer. ${ }^{39} \mathrm{He}$ is probably thinking of the Ronsardian Pléiade and wants to revive it in a specific place (Anjou) and with new members. Since, while none of the poets of Ronsard's Pléiade (Remy Belleau, Joachim Du Bellay, Jean-Antoine de Baï, etc.) actually claimed to be part of such a group, this Ronsardian imaginary concept has had a profound effect on some of his contemporaries.

36 Philibert Bugnyon (1998). "A Monsieur Neri de Torveon ... Sonnet I" (1557) Erotasmes de Phidie et Gelasine, ed. G.-A. Perouse and M.-O. Sauvajon. Paris-Geneva, Droz: 9-10.

37 Gérard-Marie Imbert (1872). Sonnet 5 "Sauf ta paix et ta grace,..." (1578). Première partie des Sonnets exotériques de Gérard Marie Imbert, ed. Ph. Tamizey de Larroque. Paris/Bordeaux, A. Claudin/G. Gounouilhou: 42.

38 Jean-Antoine de Baïf (1966). "Aus poêtes fransoês". in Euvres en rime, t. V, ed. Ch. Marty-Laveaux. Geneva, Slatkine Reprints: 323-324.

39 Pascal Robin Du Faux (1579). "Du mesme. Stanze". In Les CEuvres et meslanges poetiques de Pierre le Loyer Angevin. Paris, Jean Poupy (BnF, Rés. $\mathrm{p}-\mathrm{Ye}-146)$. 
Figure 4. Répartition des évocations Résultat de la requête "Liste des auteurs et nombre de fois qu'ls sont evoques À droite, la liste de tous les auteurs que Bastier de La Péruse a évoqués dans sa production poétique. À gauche, le curseur positionné sur un secteur du graphique fait apparaître, par exemple, que l'auteur que Bastier de La Péruse évoque e plus est Pierre de Ronsard, nommé dans trois de ses extes, soit 33,3\% des évocations de poètes par Bastier de

$$
\text { La Péruse. }
$$

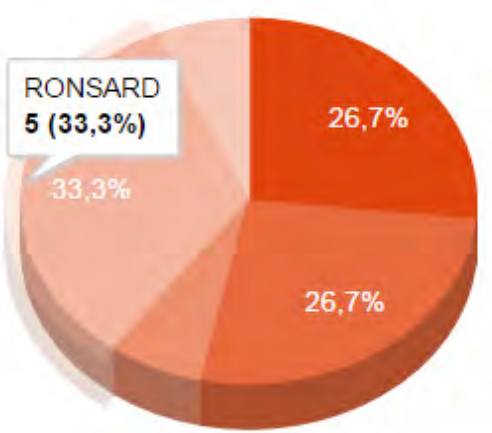

Figure 4. Distribution of mentions

Result of the search "List of authors and number of times they are mentioned by Jean Bastier de la Péruse in his whole career" (screenshot, "RéseauXPoètesXVI" database). On the right is the list of every author Bastier de la Péruse has mentioned in all of his poems. On the left is the pop-up appearing when the cursor is placed on one section of the graph: here, we can see that Pierre de Ronsard is the poet Bastier de la Péruse mentions the most frequently (Ronsard is mentioned in 3 different texts by Bastier de la Péruse, that is to say in $33.3 \%$ of all the names he has mentioned).

\section{La Pléiade : un imaginaire ronsardien structurant}

Une requête sur le mot Pléiade fait apparaître que certains regrettent de ne pas en faire partie : en 1560, dans le sonnet 69 de son recueil Le Discours, Nicolas Filleul dit sa volonté de trouver une voie de salut poétique, quoiqu'il n'appartienne pas à la Pléiade («Si me faut-il pourtant chercher un lieu aux cieux / Bien Ronsard, que ne sois luisant en ta Pléiade »). En 1578, Gérard-Marie Imbert tient le même discours dans le sonnet 8 de la Premiere partie des sonets exoteriques de G. M. D. I. (« [...] je sçay que ne suis de ta docte brigade, / Et qu'encor moins je suis de ceux de la Pleiade. / Qui dit que je ne sois le moindre des derniers ? »). Dans une «Elégie à Monsieur Le Camus parisien » publiée en 1581, mais rédigée dans les années 1560, Nicolas Rapin s'agace également en parlant de lui à la troisième personne pour déplorer une ascension poétique bloquée par l'hégémonie de la Pléiade (« Toutefois pour autant

\section{The Pléiade: A Structuring Ronsardian Imaginary}

A search for the word Pléiade reveals that some poets regret not being part of the group: in 1560, in sonnet 69 of his collection Le Discours, Nicolas Filleul talks of his desire to find a path to poetic salvation, although he does not belong to the Pléiade (" $S$ me faut-il pourtant chercher un lieu aux cieux / Bien Ronsard, que ne sois luisant en ta Pléiade" - While I must however seek a place in heaven / Though, Ronsard, I may not shine in your Pléiade.) In 1578, Gérard-Marie Imbert makes the same speech in sonnet 8 of the Premiere partie des sonets exoteriques de G. M. D. I. ("je sçay que ne suis de ta docte brigade, / Et qu'encor moins je suis de ceux de la Pleiade. / Qui dit que je ne sois le moindre des derniers ?' - I know I am not of your learned brigade, / And that even less am I of the Pléiade. / Who says that I am not the least important of them?). In "Elégie à Monsieur Le Camus parisien," published in 1581 but written in the 1560s, Nicolas Rapin is also frustrated, talking about 
qu'il n'est de la Pleiade / Et qu'il n'est point escript aux livres de ces dieux / Son ouvrage languist bien que pour faire mieux / Quelqu'un travailleroit qui a plus de bravade »). En somme, il est impossible de savoir exactement qui fait partie de la Brigade ou de la Pléiade dans l'esprit de ceux qui ont forgé ces collectifs imaginaires, car ces étiquettes ne sont jamais accompagnées de listes précises ou stables. Pourtant, ceux qui disent se situer en dehors de ces groupuscules semblent avoir une idée assez nette de qui en est et de qui n'en est pas. C'est que, comme l'écrit la sociologue Nathalie Heinich :

L'appartenance à un groupe fait rêver les écrivains qui ont le sentiment de ne pas y avoir accès, de même que l'appartenance au " milieu » littéraire peut faire rêver tous ceux - écrivains et non-écrivains - qui s'en sentent exclus. Car l'accès au milieu peut, de l'extérieur, être perçu comme une ressource prestigieuse, apte à manifester la rareté de ses membres par rapport au monde anonyme et indifférencié des simples citoyens, alors que la fréquentation de ce milieu, dès lors qu'on y a accès, se vit au contraire comme un facteur de mélange entre les êtres, d'indifférenciation entre pairs, qui fait obstacle au travail de singularisation propre à une authentique création. (Heinich 2000 : 146)

D'autres, au contraire, se réjouissent de ne pas faire partie de la Pléiade. Le réformé Henri Estienne, dans le chapitre VII de son Introduction au traité de la conformité des merveilles anciennes avec les modernes (1566) se moque de "messieurs les poëtes de la pleïade ". Le poète Florent Chrestien, dans le camp réformé également, se targue de ne pas avoir partagé leurs activités dans himself in the third person to lament poetic ascension blocked by the hegemony of the Pléiade ("Toutefois pour autant qu'il n'est de la Pleiade / Et qu'il n'est point escript aux livres de ces dieux / Son ouvrage languist bien que pour faire mieux / Quelqu'un travailleroit qui a plus de bravade" - However while he is not of the Pléiade / And he is not mentioned in the books of these gods / His work languishes although to do better / Someone with more bravado would have to work). In essence, it is impossible to know exactly who is part of the Brigade or of the Pléiade in the minds of those who dreamt up these groupings, since the labels ar never accompanied by accurate or stable lists. However, those who say that they fall outside these groupings seem to have a fairly clear idea as to who is in them and who is not. As sociologist Nathalie Heinich says:

Being part of a group is a dream for writers who feel that they do not have access to it, just as being part of the literary "milieu" may be the dream of all - both writers and non-writers - who feel excluded from it. Since access to the milieu can, from the outside, be perceived as a prestigious resource, able to demonstrate the rarity of its members in relation to the anonymous and undifferentiated world of ordinary citizens; while frequenting this milieu, once granted access, is seen conversely as a factor of mingling among individuals, a lack of differentiation among peers, which obstructs the work of originality conducive to authentic creation. (2000: 146)

Others, in contrast, are happy not to be part of the Pléiade. The Protestant Henri Estienne, in chapter seven of his Introduction au traité de la conformité des merveilles anciennes avec les modernes (1566) mocks the "messieurs les poëtes de la pleïade" (gentlemen poets of the Pléiade). The poet Florent Chrestien, also from the Protestant camp, prides himself on not having shared in their 
un « Sonnet à Ronsard» de 1563 : « Je n'ay suivy la Pleiade enyvree / Du dous poison de ton brave cerveau ». Comme ceux qui disent leur frustration de ne pas en être, ceux qui affirment leur satisfaction de rester en dehors contribuent à donner de la consistance à ce qui n'était au départ qu'un imaginaire groupal

ronsardien passager.

Cet imaginaire permet de structurer des positions : position de ceux qui dénoncent l'hégémonie ronsardienne verrouillant l'accès à la reconnaissance littéraire ou plus spécifiquement à ce qui pourrait s'apparenter en terme bourdieusien à un « sous-champ de production restreinte » (Bourdieu 1991 : 7) où s'accumule le capital symbolique ; position de ceux qui dénoncent la prétention ronsardienne à fédérer un groupe de bons poètes qui ne serait qu'un groupe de fous.

La force d'influence de Ronsard se mesure enfin aux imitations que font plusieurs poètes de quelques-uns de ses poèmes dans lesquels il valorise la sociabilité poétique au centre (et au sommet !) de laquelle il se situe. Marc-Claude Buttet, installé en Savoie après ses débuts parisiens, se plaint de sa marginalité mais en profite pour développer une sorte de domination poétique locale en modelant sa posture sur celle de Ronsard. Alors qu'en 1550 Ronsard publie un poème intitulé «A son retour de Gascogne voiant de loin Paris » (Les Quatre Premiers Livres des Odes) dans lequel il imagine ses amis accourant vers lui avec enthousiasme, Buttet publie en 1560 « Sur son retour des champs » (Le Premier Livre des vers) dans lequel il se met en scène rentrant à Chambéry (capitale des États de Savoie) où l'attendent des amis qui lui font fête. Le mètre est identique (décasyllabe) ; les deux poèmes sont composés de quatrains ; la composition et le vocabulaire présentent des similitudes. De même, imitant « Les Bacchanales ou le folastrissime voyage d'Hercueil " de 1552 (Les Amours) où Ronsard met en scène les activités champêtres activities in "Sonnet à Ronsard" from 1563: "Je n'ay suivy la Pleiade enyvree / Du dous poison de ton brave cerveau" (I have not followed the Pléiade, intoxicated / By the sweet poison of your elegant mind). Like those who express their frustration at not being a member, those who declare their satisfaction at remaining outside help give consistency to what was at the outset nothing but a fleeting, Ronsardian, imaginary group.

This imaginary is actually structuring, in terms of positions: the position of those who denounce the Ronsardian hegemony which closes off access to literary recognition, or more specifically to what could be akin in Bourdieusian terms to a "sub-field of restricted production" (Bourdieu 1991: 7) in which symbolic capital accumulates; the position of those who denounce the Ronsardian aim to unite a group of fine poets who are in fact nothing but a group of madmen.

The strength of Ronsard's influence is measured, finally, by the imitations of many poets of some of his poems highlighting the poetic sociability at the centre (and on the summit!) of which he can be found. Marc-Claude Buttet, who moved to Savoie after starting his career in Paris, complains of feeling alienated, but makes the most of his situation to develop a kind of local poetic domination, modelling his position on that of Ronsard. In 1550, Ronsard published a poem titled "A son retour de Gascogne voiant de loin Paris" (Les Quatre premiers livres des Odes) in which he imagines his friends running towards him enthusiastically; and in 1560 Buttet published "Sur son retour des champs" (Le Premier livre des vers) in which he depicts himself returning to Chambéry (capital of the Savoyard state) where his friends are waiting, and they hold a feast for him. The metre is identical (decasyllable); the two poems are composed of quatrains; the composition and wording also are very much alike. Similarly, imitating "Les Bacchanales ou le folastrissime voyage d'Hercueil" of 1552 (Les Amours) in which Ronsard presents the Brigade's 
et festives de la Brigade, Marc-Claude de Buttet dans l'ode XIX du Premier Livre des vers (1560) en reprend le thème, la composition et le rythme enjoué, mais remplace les noms cités par Ronsard par ceux de poètes locaux. Cela permet à Buttet d'adopter vis-à-vis des poètes savoyards la même attitude de chef de bande que Ronsard à Paris. Jean Vauquelin de La Fresnaye, poète poitevin, imite lui aussi les «Bacchanales » de Ronsard dans la « Description de l'aurore, pour s'aller jouer à ses compaignons êtans à Chêli. 1553 » parue en 1555 dans Les Deus Premiers Livres des Foresteries. Comme Buttet, il change les noms des poètes rassemblés pour un joyeux banquet, et ce sont cette fois-ci des poètes du Poitou.

En somme, notre mise en série de plusieurs centaines de textes témoignant de la sociabilité poétique des années 1550-1580 permet de mettre en perspective les visions ronsardiennes d'un groupe poétique élitiste - appelé Brigade ou avec un degré sélectif supérieur Pléiade - avec d'autres conceptions groupales. Elle permet également de faire entrer en écho quelques-uns des poèmes de Ronsard, exaltant une sociabilité poétique dont il est le centre, avec des imitations « locales ».

\section{De la promotion d'une génération de bons poètes} à la sociabilité mondaine

Grâce à l'empan historique que nous avons choisi, nous pouvons embrasser deux générations poétiques, la génération 1550 et la génération 1570. À l'articulation des deux éclatent les guerres de religion. Elles ont une incidence sur les relations entre poètes et entraînent une reconfiguration des amitiés affichées dont l'enregistrement des variantes des textes, dans la base de données, peut par exemple donner une idée. C'est ainsi qu'au fil des rééditions des "Isles Fortunées », Ronsard fait évoluer la liste des poètes amis invités à embarquer avec lui vers ces lieux idylliques : festive and rural activities, Marc-Claude de Buttet in ode XIX of his Premier livre des vers (1560) takes up the theme, composition, and cheerful rhythm, but replaces the names cited by Ronsard with those of local poets. This enabled Buttet to adopt the same attitude of group leader as Ronsard in Paris vis-à-vis the Savoyard poets. Jean Vauquelin de La Fresnaye, a poet from the Poitou region, also imitated Ronsard's "Bacchanales" in "Description de l'aurore, pour s'aller jouer à ses compaignons êtans à Chêli. 1553," which appeared in Les Deus Premiers Livres des Foresteries. Like Buttet, he changes the names of the poets gathered for a merry banquet, and this time they are poets from Poitou.

As a conclusion, systematically comparing several hundreds of texts reflecting the poetic sociability of the period $1550-1580$ puts Ronsard's visions of an elite group of poets - the Brigade, or with a higher degree of selectivity, the Pléiade - into perspective with other conceptual groupings. It also leads us to find echoes in "local" imitations of some of Ronsard's poems exalting a poetic sociability of which he is the centre.

\section{From the Promotion of a Generation of Fine Poets to Worldly Sociability}

Our chosen historical span actually covers two generations of poets, that of 1550 and that of 1570 . The outbreak of the French Wars of Religion link the two. The wars had an impact on relations between poets, and resulted in a reconfiguration of the friendships displayed, as reflected in various texts that are recorded in the database. Thus, over the course of the different republications of his "Isles Fortunées" ("fortunate islands"), one can see the evolution of the list of poet friends invited to set off towards these idyllic places with Ronsard: in 1560, Jacques Grévin and Jérôme L'Huillier de 
en 1560, Jacques Grévin et Jérôme L'Huillier de Maisonfleur entrent dans le bateau des happy few ; Grévin en est expulsé en 1567, L'Huillier de Maisonfleur en 1584 ; tous deux ont pris parti pour la Réforme. D'autres fois, les rééditions sont l'occasion de suppressions éloquentes : alors que le réformé Louis Des Masures offre, en 1557, une pièce de ses Carmina «Ad P. Ronsardum, \& lo. Bellaium poëtas ", il supprime ce texte de la réédition de 1574, consommant sa rupture avec le catholique Ronsard.
Maisonfleur get into the boat of the happy few; Grévin is pushed out in 1567, L'Huillier de Maisonfleur in 1584, both having taken part in the Protestant Reformation. Sometimes, republications are the occasion of potent deletions: while the Protestant Louis Des Masures included the poem "Ad P. Ronsardum, \& lo. Bellaium poëtas" in his Carmina, he removed this text from the 1574 edition, concluding his rupture with the Catholic Ronsard.

\begin{tabular}{|c|c|c|c|c|c|}
\hline \multirow{6}{*}{$\begin{array}{l}\text { Figure 5. Quelques poètes } \\
\text { de la génération } 1570-1580 \\
\text { nommés par Ronsard, Baif }\end{array}$} & & Ronsard cite... & Baïf cite... & Dorat cite... & \multirow{7}{*}{$\begin{array}{l}\text { Figure } 5 \text {. A few poets of } \\
\text { the generation } 1570-1580 \\
\text { mentioned by Ronsard, Baiff } \\
\text { and Dorat during the period } \\
1567-1585\end{array}$} \\
\hline & ... François de BELLEFOREST & 0 fois & 0 fois & 1 fois $(1570)$ & \\
\hline & ... Flaminio de BIRAGUE & 1 fois $(1583)$ & 0 fois & 3 fois $(1583-1585)$ & \\
\hline & ... Philippe DESPORTES & 1 fois (1578) & 12 fois $(1572-1581)$ & 1 fois $(1573)$ & \\
\hline & ... Guillaume Du BARTAS & 0 fois & 0 fois & 0 fois & \\
\hline & ... Clovis Hesteau de NuYsement & 0 fois & 0 fois & 3 fois (1578) & \\
\hline et Dorat sur la période $1567-$ & ... Amadis JAMYN & 6 fois $(1567-1578)$ & 0 fois & 1 fois $(1575)$ & \\
\hline Tableau réalisé sur la & ... Jean de LA GESSÉE & 0 fois & 0 fois & 3 fois $(1573-1578)$ & \multirow{3}{*}{$\begin{array}{l}\text { Table realized thanks } \\
\text { to data provided by the } \\
\text { "RéseauxPoètesXVI" } \\
\text { database. }\end{array}$} \\
\hline base des résultats des & ... GuY LE FËVRE DE LA BODERIE & 0 fois & 1 fois (1574) & 1 fois $(1578)$ & \\
\hline $\begin{array}{r}\text { requêtes faites dans } \\
\text { «RéseauxPoètes XVI ». }\end{array}$ & ... Claude TURRIN & 1 fois $(1567)$ & 0 fois & 0 fois & \\
\hline
\end{tabular}

Quelles que soient ses convictions religieuses, il est notable toutefois que la génération 1570 joue moins la carte de la rupture que la précédente pour entrer en littérature (les oppositions lexicales « jeunes »/« vieux » y sont beaucoup moins fréquentes, par exemple). De son côté, la génération 1550 se montre plus ou moins bienveillante vis-à-vis des nouveaux.

Mis à part le silence unanime qui frappe le réformé Guillaume Du Bartas, on note des attitudes différentes chez les trois poètes de la «Pléiade » retenus pour ce sondage. Jean-Antoine de Baïf affiche ouvertement son admiration et son amitié pour Philippe Desportes qui s'impose dans les années 1570 comme le poète favori de Henri III. II le nomme à douze reprises entre 1572 et 1581 et lui offre notamment un liminaire élogieux pour ses Premieres œuvres de 1573. Ronsard,

Whatever their religious beliefs, it is noticeably less common for members of the 1570 generation than it used to be for the members of the previous generations, to start a career in literature by claiming rupture (the lexical oppositions of "young"/"old" are much less frequent, for example). The 1550 generation, however, tends to be more or less benevolent towards the newcomers.

Aside from the unanimous silence which metthe Protestant Guillaume Du Bartas, there are different attitudes among the three poets of the "Pléiade" considered in this inquiry. Jean-Antoine de Baïf openly displays his admiration and friendship for Philippe Desportes, who becomes the favourite poet of Henry III in the 1570s. Baïf names Desportes twelve times between 1572 and 1581 and notably offers him an adulatory liminary text for his Premieres œuvres of 1573. 
lui, refuse tout « transfert de capital symbolique » (Saint-Amand 2013) envers Desportes, le poète chartrain. En revanche, il choisit de soutenir la production poétique de son secrétaire Amadis Jamyn, qui en retour loue à l'envi le poète vendômois. Quant à Dorat, il apparaît comme la figure la plus conciliatrice et la plus unificatrice sur toute la période 1550-1580. Professeur des jeunes Ronsard et Baïf à la fin des années 1540, il ne se montre pas aussi sélectif que ses anciens élèves et parraine de nombreux poètes dans les années 1570-1580, comme l'attestent les quelques chiffres du tableau (fig. 5) : Philippe Desportes, Jean de La Gessée, Amadis Jamyn, Clovis Hesteau de Nuysement, etc. En retour, de nombreux lettrés de la génération 1570 chantent les louanges de celui qui, depuis 1567, est « poeta regius ": Clovis Hesteau de Nuysement évoque, dans le " $\mathrm{Au}$ lecteur » de ses CEuvres poetiques (1578), "Monsieur d'Aurat [s] on precepteur » ${ }^{38}$; François de Belleforest en fait un « fanal » et un maître d'« eschole »39.

Observer les réseaux de citations sur deux générations permet aussi de mettre en valeur un double mouvement. D'une part, lorsqu'on isole les poèmes-listes de la base de données - c'est-à-dire, avons-nous choisi, ceux qui énumèrent au moins cinq poètes contemporains - le corpus de 78 pièces que l'ont obtient permet de relever que : - Les poèmes-listes sont plus fréquents sur la période 1549-1569 (54 poèmes listant 5 noms et plus dans la base de données, soit une moyenne de 2,5 listes/an) que sur la période 1570-1585 (23 listes, soit une moyenne de 1,4 liste/an);

38 Clovis Hesteau de Nuysement (1994). Les CEuvres poétiques. Livre I et II, éd. R. Guillot. Genève, Droz : 77.

39 François de Belleforest (1575). Chap. « Du pays de Limosin » dans La Cosmographie universelle de tout le monde [...] Auteur en partie Munster, mais beaucoup plus augmentée, ornée \& enrichie, par Francois de Belle-forest, Comingeois [...]. Paris, Nicolas Chesneau, exemplaire de la Bibliothèque nationale centrale de Rome, 8.26.M.5 : 114.
Ronsard refuses to enter into any "transfer of symbolic capital" (Saint-Amand 2013) with Desportes, the poet from Chartres. He chooses, however, to support the poetic production of his secretary, Amadis Jamyn, who in turn endlessly praises Ronsard. Dorat appears as the most conciliatory and unifying figure of the entire period of 1550-1580. After teaching the young Ronsard and Baïf at the end of the 1540s, he proves to be less selective than his former students were, and sponsors many poets between 1570 and 1580 , as can be seen in the table (fig. 5): Philippe Desportes, Jean de La Gessée, Amadis Jamyn, Clovis Hesteau de Nuysement, etc. In turn, many scholars of the 1570 generation sing the praises of he who had been the poeta regius since 1567: in the "Note to the Reader" of his CEuvres poetiques (1578), Clovis Hesteau de Nuysement alludes to "Monsieur d'Aurat [s]on precepteur" (Monsieur d'Aurat his tutor) ${ }^{40}$; François de Belleforest describes him as a "fanal" (beacon) and an "eschole" (school) master. ${ }^{41}$

Examining the networks of citations over the two generations also highlights a double movement. On the one hand, when list-poems are isolated in the database (among which I have chosen those listing at least five contemporary poets), the result is a body of seventy-eight poems showing that:

- list-poems are more frequent in the period 1549-1569 (fifty-four poems listing five names and more in the database, that is to say an average of 2.5 lists per year) than in the period 1570-1585 (twenty-three lists, or an average of 1.4 lists/year).

40 Clovis Hesteau de Nuysement (1994). Les CEuvres poétiques. Livre I et II, ed. R. Guillot. Geneva, Droz: 77.

41 François de Belleforest (1575). Chap. "Du pays de Limosin." In La Cosmographie universelle de tout le monde [...] Auteur en partie Munster, mais beaucoup plus augmentée, ornée \& enrichie, par Francois de Belleforest, Comingeois [...]. Paris, Nicolas Chesneau, (copy of the Rome National Central Library, 8.26.M.5): 114 
- Les poèmes-listes comportent en moyenne plus de noms sur la période 1549-1569 (9,4 noms/liste) que sur la période 1569-1585

(8,4 noms/liste)
- list-poems contain on average more names during the 15491569 period (9.4 names/list) than in the $1569-1585$ period ( 8.4 names/list)

Figure 6. Nombre de pièces liminaires et postliminaires dans quelques recueils poétiques entre 1549 et 1585 Tableau réalisé sur la requêtes faites dans "RéseauXPoètesXVI ».

\begin{tabular}{|l|l|}
\hline Recueil & $\begin{array}{l}\text { Couronne } \\
\text { encomiastique }\end{array}$ \\
\hline L'Olive de J. Du Bellay (1549) & 1 pièce \\
\hline L'Olive augmentée de J. Du Bellay (1550) & 2 pièces \\
\hline Quatre premiers livres des Odes de P. de Ronsard (1550) & 9 pièces \\
\hline Les Amours... Ensemble le cinquiesme de ses Odes de Ronsard (1552), section « Amours » & 3 pièces \\
\hline Les Amoureuses occupations de G. La Tayssonniere (1555) & 2 pièces \\
\hline Quatre livres de l'amour de Francine de J.-A. de Baïf(1555) & 2 pièces \\
\hline Erotasmes de Phidie et Gelasine de Ph. Bugnyon (1557) & 8 pièces \\
\hline Les Sonets amoureux par C. D. B. de Ch. d'Espinay (1559) & 9 pièces \\
\hline L'Olimpe de J. Grevin (1560) & 5 pièces \\
\hline Le Theatre de J. Grevin (1561) & 4 pièces \\
\hline Porcie de R. Garnier (1568) & 3 pièces \\
\hline Les premieres ceuvres de Sc. de Sainte-Marthe (1569) & 9 pièces \\
\hline Les Premieres ceuvres de Ph. Desportes (1573) & 4 pièces \\
\hline Les Euvres poetiques d'A. Jamyn (1575) & 5 pièces \\
\hline Les poemes de P. de Brach (1576) & 12 pièces \\
\hline La Galliade de G. Le Fèvre de La Boderie (1578) & 10 pièces \\
\hline Les oeuvres poetiques de Cl. Hesteau de Nuysement (1578) & 15 pièces \\
\hline Les ouvres et meslanges poetiques de P. Le Loyer (1579) & 12 pièces \\
\hline Les euvres poetiques de J. de Courtin de Cissé (1581) & 10 pièces \\
\hline Les premieres ceuvres poetiques de Fl. de Birague(1585) & 23 pièces \\
\hline
\end{tabular}

Figure 6. Number of liminary and post-liminary texts in a few collections of poems between 1549 and 1585 Table realized thanks to data provided by the "RéseauxPoètesXVl" database.
On peut supputer que l'enthousiasme de la première heure, qui poussait les poètes à se représenter comme un collectif nombreux, comme une déferlante, a été tempéré par les guerres de religion. Par ailleurs, lorsqu'on observe les couronnes encomiastiques, on note qu'elles prennent de l'ampleur au fil des décennies, comme peuvent en témoigner ces quelques jalons (fig. 6) :
The original enthusiasm that encouraged poets to represent themselves as a large collective, like a flood, had probably been tempered by the wars of religion. Moreover, encomiastic honours increase in number over the decades, as can be seen from these few milestones (fig. 6). 
Ainsi, la mise en valeur de la sociabilité lettrée a tendance à se déplacer du cœur de l'œuvre (les poèmes-listes qu'un poète rédige pour valoriser le collectif dans lequel il s'insère) vers la périphérie de l'œuvre (les liminaires et postliminaires dont la juxtaposition crée un effet de liste). La promotion poétique de collectifs de poètes enthousiastes cède aussi la place à l'affichage mondain de cautions massées à l'ouverture et à la fermeture du recueil. $\mathrm{Ce}$ mouvement suit le passage des règnes de Henri II et Charles IX - les années 1550-1560 que l'histoire littéraire a désignées par l'étiquette «Pléiade » - à l'avènement de Henri III, « homme de Cour et pénitent, mondain, dépensier et dévot ", " homme du spectacle toujours dans le paraitre » (Fragonard $1992: 48$ ), dont le poète favori est Philippe Desportes.

Une histoire littéraire ni uniquement masculine, $\mathrm{ni}$ uniquement parisienne, ni uniquement canonique

Enfin, notre base de données permet de mettre en valeur quantité de poètes peu connus que l'on n'a guère l'habitude d'intégrer à l'histoire littéraire de la période 1550-1580. Parce que l'outil informatique nous assurait la capacité de pouvoir naviguer facilement entre un grand nombre de textes, nous nous sommes autorisée à dépouiller bien plus de recueils et à relever bien plus de textes que ce que nous aurions fait sans son appui, de crainte d'être dépassée par la masse documentaire.

De la sorte, nous pouvons prendre en compte des poètes peu souvent valorisés dans les études seiziémistes afin de les relier au réseau, soit par le biais de poèmes liminaires qu'ils auraient offerts à des poètes plus célèbres, soit par le biais d'un recueil peu connu de nos jours qu'ils ont publié et qui contient des pièces mentionnant des confrères, soit encore parce qu'ils sont les destinataires occasionnels des poètes dont nous avons dépouillé les œuvres.
The emphasis on scholarly sociability thus tends to shift from the heart of the work (as in the list-poems written by a poet to showcase the wider collective he is part of) towards the periphery of the work (liminary and postliminary texts - the juxtaposition of which creates a list effect). The promotion through poetry of enthusiast groups of poets also gives way to showy displays of amassed endorsements at the start and end of the collection. This movement follows the reigns of Henry II and Charles IX - the 1550-1560s, which literary history has labelled "Pléiade" - until the accession of Henry III, "homme de Cour et pénitent, mondain, dépensier et dévot," (a courtier and a, worldly, prodigal, and devout penitent), "homme du spectacle toujours dans le paraitre" (a man of spectacle for whom appearance is essential) (Fragonard 1992: 48), whose favourite poet was Philippe Desportes.

\section{A Literary History that is Not Uniquely Male, Nor Uniquely Parisian, Nor Uniquely Canonical}

Finally, the database can be used to bring to light a number of littleknown poets usually excluded from literary history of the 15501580 period. Thanks to data-processing which allows for an easy navigation between a large number of texts, I was able to examine many more collections and collect many more texts than I would have without it, for fear of being overrun by the sheer number of documents.

It was therefore possible for me to take into account poets whose name is rarely emphasized in sixteenth-century studies, and to link them to the network either through liminary poems offered to betterknown poets; or via little-known collections which they published containing poems mentioning colleagues; or because they were occasional addressees of poets whose works I scrutinized. For instance, a liminary sonnet by Roland Du Jardin given to Clovis 
Là, un sonnet liminaire de Roland Du Jardin offert à Clovis Hesteau de Nuysement pour ses CEuvres poetiques de $1578^{40}$ attire notre attention parce qu'il met en balance deux astres : le Soleil/Ronsard et la Lune/Nuysement. Ici, nous nous sommes intéressée au recueil publié par Maclou de La Haye en 1553 (Les CEuvres de Maclou de La Haye, Piccard) parce que Ronsard et Du Bellay citaient son nom comme compagnon de la première heure. Celui-ci leur rend bien I'honneur : il compte parmi les premiers à consacrer ouvertement Ronsard comme "Prince des Poëtes ${ }^{41}$ "; il fait de l'angevin Du Bellay un « ange divin ${ }^{42} »$. Souvent, ces poètes peu connus, que nous avons pu intégrer à notre compte rendu du foisonnement poétique des années 1550-1580, sont ancrés en province : Gérard-Marie Imbert (de Condom) et Jean de Boyssières (de Clermont-Ferrand) rejoignent, par exemple, le grand théâtre des sociabilités littéraires dont nous pouvons rendre compte grâce à « RéseauxPoètesXVI ».

Enfin, l'ouverture de la focale permet de faire une place aux femmes. Nous avons dépouillé le plus possible de recueils de poétesses et recueilli ainsi des pièces de contact d'autrices comme les Dames Des Roches qui animent un salon lettré à Poitiers dans les années 1570-1580 ou Marie de Romieu qui soupire « [...] par fois

40 Clovis Hesteau de Nuysement (1994). Les CEuvres poétiques, Livre I et II, éd. R. Guillot. Genève, Droz : 106.

41 Maclou de La Haye (1553). Les CEuvres de Maclou de La Haye, Piccard. Paris, É. Groulleau (BnF, Rés. P-Ye-373) : 52, v. 14. En 1552, Marc-Antoine de Muret avait déjà publié dans les Juvenilia une ode intitulée «Ad Petrum Ronsardum gallicorum poëtarum facile principem " soit “ À Pierre de Ronsard de loin le prince des poètes français ». En 1553, la même année que Maclou de La Haye, Jean-Bastier de La Péruse s'adresse lui aussi, dans un sonnet liminaire offert pour Le Cinquieme des odes de P. de Ronsard, à «P. de Ronsard prince des poètes françois ».

42 Maclou de La Haye (1553). Les CEuvres de Maclou de La Haye, Piccard. Paris, É. Groulleau (BnF, Rés. P-Ye-373) : 56, v. 7.
Hesteau de Nuysement for his CEuvres poetiques of $1578^{42}$ attracted my attention because it balances "the Sun" (Ronsard) with "the Moon" (Nuysement). Similarly I was interested in the collection published by Maclou de La Haye in 1553 (Les CEuvres de Maclou de La Haye, Piccard) because Ronsard and Du Bellay cite his name as an early companion. Maclou de La Haye shows his appreciation by being among the first to openly call Ronsard the "Prince of Poets"43; and to make of Du Bellay, born in Anjou (therefore an Angevin), a "divine angel" 44 (playing with the assonance angevin/ ange divin). These little-known poets included in our account of the poetic profusion of 1550-1580 are often anchored in the provinces: Gérard-Marie Imbert (from Condom) and Jean de Boyssières (from Clermont-Ferrand), for example, join the great performance of literary sociability that "RéseauXPoètesXVI" makes visible.

Finally, by widening the focus, the role of women can be recognized. We surveyed as many collections as possible by female poets and thus compiled their references to other poets. Among these women, there are the Dames Des Roches, for instance, who conduct a literary salon in Poitiers between 1570 and 1580, or

42 Clovis Hesteau de Nuysement (1994). Les CEuvres poétiques, Livre I et II ed. R. Guillot. Geneva, Droz: 106.

43 Maclou de La Haye (1553). Les CEuvres de Maclou de La Haye, Piccard. Paris, É. Groulleau (BnF, Rés. P-Ye-373): 52, v. 14. In 1552, Marc-Antoine de Muret had already published an ode in Juvenilia entitled "Ad Petrum Ronsardum gallicorum poëtarum facile principem" (To Pierre de Ronsard, far and away the prince of French poets). In 1553, the same year that Maclou de La Haye and Jean-Bastier de La Péruse addressed Ronsard in a liminary sonnet for Le Cinquieme des odes de P. de Ronsard, to " $P$. de Ronsard prince des poètes francois" ( $\mathrm{P}$. de Ronsard, prince of French poets).

44 Maclou de La Haye (1553). Les CEuvres de Maclou de La Haye, Piccard. Paris, É. Groulleau (BnF, Rés. P-Ye-373): 56, v. 7. 
je voudrois estre, / [...] ce divin Ronsard, la gloire des François ${ }^{43}$ " (1581). Elles sont soutenues par des hommes. Ronsard et Dorat offrent, par exemple, des liminaires à Anne de Marquets pour ses Sonets, prieres et devises, en forme de Pasquins (1562) et Scévole de Sainte-Marthe loue ses « beaux vers » qu'il dit lire « cent fois le jour » dans un sonnet de 1569 qu'il lui dédicace ${ }^{44}$. Les poétesses apparaissent toutefois trop peu nombreuses, trop espacées dans le temps et dédiées à des genres trop différents (la poésie érotique pour Louise Labé en 1555, la poésie religieuse catholique pour Anne de Marquet en 1562 et 1569, la poésie religieuse réformée pour Georgette de Montenay, en 1567, etc.) pour " faire réseau » entre elles. En revanche, l'observation des pièces liminaires de l'ensemble des recueils de notre corpus permet de relever l'apparition de signatures féminines de poétesses occasionnelles dans les seuils des œuvres masculines, notamment à partir des années 1570. Les femmes semblent ainsi acquérir une voix capable de légitimer une œuvre masculine : il en va ainsi de Madeleine de L'Aubespine (un liminaire pour les Premières œuvres de Desportes en 1573), de Marguerite Le Loyer (un liminaire pour Les CEuvres et meslanges poetiques de Pierre Le Loyer en 1579), de Madeleine de Saint-Gelais (un liminaire pour Les Premieres CEuvres poetiques de

Flaminio de Birague en 1585), et de quelques autres.

43 Marie de Romieu (1972). Les Premières CEuvres poétiques, éd. A. Winandy. Genève/Paris, Droz/Minard : 99, v. 1-2.

44 Scévole de Sainte-Marthe (2010). CEuvres complètes I, éd. J. Brunel. Genève, Droz : 793, v. 1.
Marie de Romieu, who sighs, "par fois je voudrois estre, / ... ce divin Ronsard, la gloire des François" 45 (sometimes I would like to be, / ... this divine Ronsard, the glory of the French) (1581). They are supported by men. For example, Ronsard and Dorat give Anne de Marquets liminary texts for her Sonets, prieres et devises, en forme de Pasquins (1562), and Scévole de Sainte-Marthe claims to read her "beaux vers" (fine verse) "cent fois le jour" (a hundred times a day) in a sonnet dedicated to her from $1569 .{ }^{46}$ Female poets, however, are too few, too spread out over time, and dedicated to too many different genres (erotic poetry for Louise Labé in 1555 Catholic religious poetry for Anne de Marquet in 1562 and 1569; Protestant poetry for Georgette de Montenay in 1567, etc.) to form a network between them. But, studying liminary texts across the collections in the corpus reveals the signatures of occasional female poets in works by men, especially from 1570 onwards. Women thus appear to acquire a voice capable of legitimizing a male work: this is the case for Madeleine de L'Aubespine (a liminary text for Desportes' Premières cuvres in 1573); Marguerite Le Loyer (a liminary text for Pierre le Loyer's Les CEuvres et meslanges poetiques, 1579); and Madeleine de Saint-Gelais (a liminary text for Flaminio de Birague's Les Premieres CEuvres poetiques, 1585), plus a few more.

45 Marie de Romieu (1972). Les Premières œuvres poétiques, ed. A. Winandy Geneva/Paris, Droz/Minard: 99, v. 1-2.

46 Scévole de Sainte-Marthe (2010). CEuvres complètes I, ed. J. Brunel. Geneva, Droz: 793, v. 1 


\section{La défense collective d'une spécificité et d'une visibilité du groupe des poètes}

Autoréflexivité et valorisation du corps des poètes

Au-delà de ces analyses de détail sur l'étendue et la richesse des transferts de crédits entre lettrés, sur la multiplicité des principes de regroupement, ou sur la position de tel ou tel poète au sein du réseau, la base de données permet de soutenir avec Gisèle Mathieu-Castellani que « l'un des traits caractéristiques de la poésie de la Pléiade est sans doute son activité auto-réflexive " (MathieuCastellani $1986: 659)$. Là où la chercheuse pensait surtout à la réflexion des poètes sur l'écriture, nous avons voulu mettre en valeur leur réflexion sur ce qui les lie les uns aux autres et leur permet de constituer un ou des groupes spécifiques. Le nombre important de pièces que rassemble «RéseauxPoètesXVI 》 atteste ainsi d'une volonté forte des poètes de se montrer en dialogue avec leurs pairs, voire de faire corps, même si des querelles peuvent les diviser et si les portraits de poètes en groupe sont souvent l'occasion d'établir des hiérarchies internes. Ce faisant, les auteurs de notre corpus - dont Alain Viala a souligné qu'ils avaient « placé la poésie au centre de la scène sociale pour longtemps » (Viala 2014 269) - nous semblent œuvrer collectivement à un renforcement de la visibilité des poètes et du prestige de la poésie, notamment aux yeux des grands du royaume auxquels, rappelons-le, une large majorité de leurs recueils sont dédiés.

De fait, l'effet de loupe qu'entraîne un corpus constitué d'une sélection de textes extraits d'un ensemble plus vaste ne doit pas faire oublier que la majeure partie de la production poétique de cette période est tournée vers le roi et vers les grands du royaume. Ces derniers, à la suite de la « révolution culturelle » engagée par François $1^{\mathrm{er}}$ (Gadoffre 1997), sont enclins à protéger les lettres

\section{The Collective Defence of the Specificity and Visibility of the Group of Poets}

\section{Self-Reflexivity and Promotion of the Poet's Status}

Beyond detailed analyses of the extent and abundance of these transfer of credits between scholars, of the various types of groupings, or of the particular position of a poet or another within the network, the database supports the claim by Gisèle MathieuCastellani that "one of the characteristic traits of the poetry of the Pléiade is undoubtedly its self-reflexive activity" (MathieuCastellani 1986: 659). While Mathieu-Castellani considers above all the reflection of poets on writing, I want to highlight their reflection on what links them together and allows them to form one or several specific groups. The considerable number of poems brought together by "RéseauxPoètesXVI" demonstrates the poets' strong desire to be seen to be in dialogue with their peers, or even to be part of a profession, although they may be divided by disagreements, and despite the fact that depictions of groups of poets often provide an opportunity to establish internal hierarchies. This being the case, poets in our corpus - who Alain Viala points out had "long put poetry at the centre of the social scene" (Viala 2014: 269) - appear to work collectively to strengthen the visibility of poets and of the prestige of poetry, especially in the eyes of the nobility of the kingdom, to whom, we should remember, the majority of their collections are dedicated.

Indeed, the magnifying effect of a corpus composed of a selection of texts taken from a larger set should not obscure the fact that the majority of poetic production of this period is directed at the king and the nobility. The latter, following the "cultural revolution" instigated by Francis I (Gadoffre 1997), are inclined to protect the arts since this is now a source of social prestige (Charton-Le-Clech 1993; 
puisqu'elles sont désormais pourvoyeuses de prestige social (Charton-Le-Clech 1993 ; Gadoffre 1997). Mais encore faut-il, pour les poètes, arriver à séduire les mieux placés d'entre eux, qui servent souvent de relais vers le roi (Buron 2006). À l'évidence, la seule préoccupation des poètes n'est donc pas de nourrir un dialogue entre pairs et de se distribuer réciproquement des marques de crédit. Les échanges d'éloges entre confrères soutiennent les stratégies de carrière de ces hommes qui cherchent des protecteurs et mécènes afin d'obtenir des moyens d'existence sous forme de pensions, de bénéfices ecclésiastiques ou d'emplois à des fonctions diverses (secrétaire, lecteur, etc.). Michel Simonin a ainsi montré combien les manœuvres pour obtenir des prieurés, les trocs de bénéfices et les trafics en tous genres avaient accaparé une partie de l'énergie de Ronsard (Simonin 1990). En d'autres termes, à la Renaissance il n'y a pas de dynamique d'autonomisation du « champ littéraire » semblable à ce qu'a pu mettre au jour Pierre Bourdieu pour le XIX ${ }^{\mathrm{e}}$ siècle (Bourdieu 1991 et 1992).

Toutefois, en se citant mutuellement pour augmenter leur notoriété et obtenir les meilleures places auprès des puissants, les poètes organisent leur visibilité et cherchent à faire grandir la valeur du corps des poètes. II leur arrive d'ailleurs de se présenter comme des ouvriers tailleurs de monuments ${ }^{45}$ et d'utiliser le terme de

45 Jacques Grévin (1560). « Pour le tombeau de Joachim Du Bellay ». L'Olimpe de Jaques Grévin de Cler-Mont en Beauvaisis. Ensembles autres euvres Poëtiques dudict Auteur. Paris, Robert Estienne (exemplaire de la BnF, Rés. Ye-180) : 188, v. 61-65 ; Jean-Antoine de Baï (1966) [1881]. «A Monsieur Garnier conseiller au siege presidial du Mans » (1573). In Euvres en rime, t. IV, éd. C. Marty-Laveaux. Genève, Slatkine Reprints : 444, v. 13 ; JeanAntoine de Baïf (2002). «A Phelippes des Portes » (1573) dans OC I, éd. J. Vignes. Paris, Champion : 374, v. 42-43 : « Toy qui es un sçavant ouvrier / Avec moy d'un mesme mestier », écrit Baïf à Desportes.
Gadoffre 1997). But poets have to charm those best-placed among them, who often serve as a link to the king (Buron 2006). Thus poets are clearly not only concerned with sustaining dialogue between peers and mutually handing out symbols of credit. Exchanges of praise between colleagues support the career strategies of these men who are looking for protectors and patrons in order to make a livelihood in the form of grants, ecclesiastic benefits, or various positions of employment (secretaries, readers, etc.) Michel Simonin shows how a good deal of Ronsard's energy is taken up with manoeuvres to acquire priories, benefit bartering, and trafficking of all types (Simonin 1990). In other words, during the Renaissance there is no autonomization of the "literary field" as Pierre Bourdieu has shown for the nineteenth century (Bourdieu 1991 and 1996).

Nevertheless, by mutually citing each other to increase their notoriety and get the best positions with respect to powerful figures, poets organize their visibility and seek to increase recognition of the poetry status. They come to present themselves, for that matter, as stonemasons and constructors of monuments, ${ }^{47}$ using

47 Jacques Grévin (1560). "Pour le tombeau de Joachim Du Bellay," L'Olimpe de Jaques Grévin de Cler-Mont en Beauvaisis. Ensembles autres euvres Poëtiques dudict Auteur. Paris, Robert Estienne, BnF copy, Rés. Ye-1807, p. 188, v. 61-65. Jean-Antoine de Baiff (1966) [1881]. "A Monsieur Garnier conseiller au siege presidial du Mans" (1573). In Euvres en rime, t. IV, ed. C. Marty-Laveaux. Geneva, Slatkine Reprints: 444, v. 13. Jean-Antoine de Baïf (2002] "A Phelippes des Portes" (1573) in CEuvres complètes I, ed. J. Vignes. Paris, Champion: 374, v. 42-43: "Toy qui es un scavant ouvrier Avec moy d'un mesme mestier" (You who are a learned builder / With me of the same profession') wrote Baif to Desportes. 
« compagnons ${ }^{46}$ » pour désigner leur groupe. Le mot pointe alors vers l'idée d'« association de solidarité entre ouvriers d'un même corps de métier » (définition du TLFi) qu'est le compagnonnage. Les poètes alimentent ainsi un discours sur la spécificité de la poésie et participent à la défense d'une « autonomie-spécificité 》 de la littérature. Bernard Lahire invite, en effet, à distinguer d'une part l'autonomie-spécificité de la littérature - « c'est-à-dire son existence comme domaine particulier d'activité qui se distingue d'autres domaines » (2012:80) - et d'autre part l'autonomie-indépendance vis-à-vis des pouvoirs politiques, religieux ou économiques. Or, écrit-il, l'autonomie-spécificité « n'a pas attendu la fin du XIX ${ }^{\mathrm{e}}$ siècle pour s'accomplir » (2012: 79) et, en ce qui concerne l'autonomieindépendance, « la seule chose que l'on puisse dire avec certitude, c'est que l'on est passé historiquement d'une dépendance des écrivains à l'égard des pouvoirs politiques et religieux, financeurs et commanditaires d'œuvres, à une dépendance générale par rapport au marché » (2012: 82). Sans doute toutes les représentations des relations entre poètes que nous avons recensées participentelles d'une réflexion et d'une mise en valeur de la spécificité du groupe des poètes. Sans être une innovation - car l'autonomiespécificité n'a sans doute pas non plus attendu la seconde moitié $\mathrm{du} x \mathrm{XV} \mathrm{I}^{\mathrm{e}}$ siècle -, elles attirent l'attention par leur grand nombre, par leur caractère public (car publié) et par les esquisses qu'elles contiennent parfois d'un espace séparé doté de règles spécifiques.

\section{Mises en scène d'un groupe spécifique} et velléités d'autonomie ?

Nous l'avons dit, une partie de notre corpus est composée de pièces liminaires que les poètes s'échangent pour organiser une sorte de

46 Pierre de Ronsard (1939). « Elegie à Loïs des Masures tournisien » (1560). CEuvres complètes X, éd. P. Laumonier. Paris, Droz : 362-370, not. v. 85-92. the term "companions" 48 to refer to their group. The word suggests the idea of an "association of solidarity between workers of the same professional field" (definition from the Trésor de la langue française informatisé), as in the guild system. Poets thus fuel discourse on the specificity of poetry, and participate in supporting a "specificity-autonomy" of literature. Indeed, Bernard Lahire calls for a distinction between, on the one hand, the specificityautonomy of literature - "that is to say its existence as a particular sphere of activity distinct from other spheres" (2012: 80) - and on the other hand the independence-autonomy vis-a-vis political, religious, and economic powers. For him, independence-autonomy "came about before the end of the nineteenth century" (2012: 79), and "the only thing we can say with certainty is that historically we went from writers' dependence on political and religious powers, financiers, and sponsors of works, to general dependence on the market" (2012: 82). Without doubt, all the identified representations of relations between poets involve a reflection on and promotion of the specificity of the group of poets. Without being an innovation - since specificity-autonomy undoubtedly came about even before the second half of the sixteenth century - the representations attract attention for their great number, their public character (since they were published), and the sketches they sometimes contain of a space apart with its own rules.

\section{Presentation of a Specific Group and the Illusion of Independence?}

As said before, a portion of the corpus studied here is composed of liminary texts exchanged among poets, which provide a kind

48 Pierre de Ronsard (1939) . "Elegie à Loïs des Masures tournisien" (1560). In CEuvres complètes X, ed. P. Laumonier. Paris, Droz: 362-370, not. v. 85-92. 
haie d'honneur à l'orée de leurs recueils. Nous avons par ailleurs observé que leur nombre augmente globalement au fil des ans. Pour Michel Simonin, qui s'est intéressé à la pratique encomiastique de Ronsard, l'augmentation des pièces liminaires dans les recueils au cours du $\mathrm{XVI}^{\mathrm{e}}$ siècle est riche de sens : "En vérité, nous tenons là un indice de la constitution spontanée d'une institution littéraire et de la mise au point tâtonnante des règles destinées tout à la fois à la régir et à la promouvoir » (Simonin 2004 [1985] : 336). Lieu d'évaluation entre pairs, les couronnes encomiastiques qui entourent l'œuvre de l'auteur offrent donc aux lettrés un espace dans lequel ils peuvent organiser leur petit monde - un petit monde qui peut d'ailleurs s'avérer plus tyrannique que les cours royales ou princières, stipule Michel Simonin, car quand c'est l'ami qui prie le poète d'écrire quelques vers, il s'agit d'une " contrainte beaucoup plus forte que celle qu'exercent par exemple les commandes royales » (Simonin 2004 [1985] : 345).

Ces couronnes encomiastiques suggèrent que les premiers lecteurs et critiques des poètes sont les poètes. C'est ce qu'affirme désirer Du Bellay lorsqu'il écrit dans le «Au lecteur » de L'Olive de 1549 " Je ne cherche point les applaudissemens populaires. II me suffit pour tous lecteurs avoir un S. Gelays, un Heroët, un de Ronsart, un Carles, un Sceve, un Bouju, un Salel, un Martin, et si quelques autres sont encor'à mettre en ce ranc. A ceulx là s'addressent mes petiz ouvraiges. Car s'ilz ne les approuvent, je suis certain pour le moins qu'ilz louront mon entreprise ${ }^{47}$. " L'affirmation est contredite par le recours à la publication imprimée - qui n'était vraisemblablement pas nécessaire pour un lectorat si restreint et par la dédicace de l'œuvre à " tresillustre Princesse Madame Marguerite seur unique du Roy » (sonnet liminaire). Par ailleurs, les

47 Joachim Du Bellay (2007). La Deffence, et illustration de la langue françoyse \& L'Olive, éd. J.-C. Monferran et E. Caldarini. Genève, Droz : 356. of guard of honour at the start of their collections, and whose number generally increases over the years. For Michel Simonin, who is interested in Ronsard's encomiastic practice, the increase in liminary texts in collections during the sixteenth century is highly significant: "What we have here, in truth, is an indication of the natural formation of a literary institution, and of the tentative elaboration of rules destined to both determine and promote it" (Simonin 2004 [1985]: 336). Encomiastic honours which encompass a poet's work, are a space where an estimation between peers can take place, therefore offering men and woman of letters a platform from which to organize their little world. This little world can actually be more tyrannical than the royal or prince's courts, according to Michel Simonin, since when a friend is supplicating the poet to write verse, this is a "much stronger contract than those imposed, for example, by royal commission" (Simonin 2004 [1985]: 345).

These encomiastic honours suggest that the first readers and critics of poetry were poets. This is what Du Bellay claims in the "Note to the Reader" for L'Olive, 1549: "Je ne cherche point les applaudissemens populaires. II me suffit pour tous lecteurs avoir un S. Gelays, un Heroët, un de Ronsart, un Carles, un Sceve, un Bouju, un Salel, un Martin, et si quelques autres sont encor' à mettre en ce ranc. A ceulx là s'addressent mes petiz ouvraiges. Car s'ilz ne les approuvent, je suis certain pour le moins qu'ilz louront mon entreprise." 49 (I do not look in any way for popular approval. For all readers, it is enough for me to have an S. Gelays, a Heroët, a Ronsart, a Carles, a Sceve, a Bouju, a Salel, a Martin, and if there are still more to add to this rank. I address my little works to them. Since while they may not approve them, I am at least certain

49 Joachim Du Bellay (2007). La Deffence, et illustration de la langue françoyse \& L'Olive, ed. J.-C. Monferran and E. Caldarini. Geneva, Droz: 356. 
noms cités servent surtout, pour la plupart, de cautions poétiques pour le débutant Du Bellay. Toutefois, l'assertion esquisse l'idée d'un monde poétique qui produit pour lui-même.

Une autre partie de notre corpus, nous l'avons précisé, est composée de poèmes-listes qui sont l'occasion de dresser des palmarès ou d'énumérer simplement les noms de quelques poètes contemporains estimés. II est intéressant de noter que le contexte est plusieurs fois celui d'une sortie à la campagne ou celui d'une réunion sur une île. Dans les «Bacchanales » (1552) et dans «Les Isles Fortunées » (1553) - deux poèmes qui dressent des listes de confrères participant d'une sociabilité heureuse -, Ronsard utilise l'anaphore «Partons... Partons... ». Dans le premier cas, il s'agit de quitter Paris pour aller dans la campagne environnante ; dans le second cas, il s'agit de quitter l'Europe en proie aux déchirements religieux pour se rendre aux «Isles Fortunées ». Dans ces lieux à l'écart peut s'épanouir une sociabilité poétique joyeuse. Dans la veine des «Isles Fortunées », Philibert Bugnyon chante "L'Isle Pontine » $(1557)^{48}$ sur laquelle peuvent se réunir les poètes. Pontine parce qu'elle appartiendrait à Pontus de Tyard, cette île accueille des poètes de la région mâconnaise (Guillaume Des Autels, François Tartaret, Gratian Chandon, etc.). L'île Pontine et les îles Fortunées relèvent de l'imaginaire insulaire fabuleux : la première, sous la plume de Bugnyon, est peuplée de déesses et de dieux de la mythologie ; les

48 Philibert Bugnyon (1998). «Chant panegyric » (1557), Erotasmes de Phidie et Gelasine, éd. G.-A. Pérouse et M.-O. Sauvajon. Genève, Droz : 192-205 that they will appreciate my project). This assertion is contradicted by the use of print publication - which is arguably unnecessary for such a restricted readership - and by the dedication of the work to "tresillustre Princesse Madame Marguerite seur unique du Roy" (the most illustrious Princess Madame Marguerite, only sister of the King). In addition, the names mentioned serve, above all, as poetic endorsements for newcomer Du Bellay. Nevertheless, the assertion gives the impression of a world of poetry which produces for itself.

Another section of the corpus studied, as indicated, is composed of list-poems, which constitute an opportunity to establish rankings or simply to list the names of esteemed contemporary poets. It is interesting to note that the context is often that of a trip to the country or a meeting on an island. In "Bacchanales" (1552) and "Les Isles Fortunées" (1553) - two poems which draw up lists of colleagues participating in "happy" sociability - Ronsard uses anaphora: "Partons... Partons..." (Let's leave ... Let's leave ...). In the first case, they are leaving Paris to go to the surrounding countryside; in the second, they are leaving a Europe beset by religious rifts to go to the "Isles Fortunées." In these places set apart, joyous poetic sociability can flourish. In the vein of "Isles Fortunées," Philibert Bugnyon extols "L'Isle Pontine" (1557) ${ }^{50}$ where poets can gather. Called Pontine because it belongs to Pontus de Tyard, Pontine Island welcomes poets from the Mâconnais district (Guillaume Des Autels, François Tartaret, Gratian Chandon, etc.). Pontine and the Isles Fortunées are examples of legendary imaginary insular worlds: Bugnyon's Pontine is populated by gods and goddesses of mythology; and the Isles Fortunées can amount to a utopia since, while identified geographically as the Canary Islands, they

50 Philibert Bugnyon (1998). "Chant panegyric," (1557), Erotasmes de Phidie et Gelasine, ed. G.-A. Pérouse and M.-O. Sauvajon. Geneva, Droz: 192-205. 
îles Fortunées, quant à elles, peuvent s'apparenter à une utopie car, même si elles sont identifiées géographiquement aux îles Canaries, elles sont associées dans les imaginaires antiques au mythe de l'âge d'or et constituent une légende. Dans ces exemples, le désir de la liberté champêtre et l'imaginaire insulaire permettent de situer les réunions de poètes dans un lieu à l'écart qui est parfois un lieu clos (une île). II se construit donc là, sans doute, la représentation d'un espace poétique distinct des autres espaces sociaux. Toutefois, cette esquisse est fragile. Soit les velléités d'autonomie vis-à-vis des contraintes politiques et des contingences matérielles tournent court lorsque la troupe de poètes doit rentrer à Paris avec un peu d'amertume après la partie de campagne («Les Bacchanales ${ }^{49}$ »). Soit l'éloignement, voire l'autarcie, ne relèvent que d'une projection fantasmatique : le voyage des poètes vers les îles Fortunées n'est qu'une vision de l'esprit ronsardien ; «L'Isle pontine », si elle repose sur un substrat historique, se clôt sur un rêve : celui que Ronsard et Du Bellay rejoignent l'île un jour.

\section{Convergence de faisceaux}

Notre étude de la mise en scène des réseaux de poètes dans la seconde moitié du $\mathrm{XVl} \mathrm{l}^{\mathrm{e}}$ siècle entre en écho avec d'autres analyses qui peuvent converger. Jean-Charles Monferran, dans L'École des Muses, s'est intéressé non pas aux pièces de contact entre les poètes de la «Pléiade » mais aux arts poétiques des années 1550 qui valorisent des productions contemporaines. Selon lui, l'Art poetique françois de Sébillet (1548), la Deffence de Du Bellay

49 «Donque, puis que la nuit sombre, / Pleine d'ombre, / Vient les montaignes saisir, / Retournon troupe gentille / Dans la ville, / Demisoulez de plaisir. Jamais l'homme tant qu'il meure, / Ne demeure / Fortuné parfaictement, / Tousjours avec la lyesse / La tristesse / Se mesle segrettement » (v. 631-642, derniers vers du poème, Pierre de Ronsard (1921). In CEuvres complètes III, éd. P. Laumonier. Paris, Hachette : 216-217) are associated in the ancient imaginary world with the myth of the golden age, and constitute legend. In these examples, the desire for bucolic freedom and the imagined insular world allow meetings of poets to take place somewhere faraway, and often within a confined space (an island). This undoubtedly forms the representation of a poetic space that is separate from other social spaces. However, this idea is a fragile one. Either the desire for autonomy from political constraints and material concerns fade once the group of poets has to return to Paris with some bitterness following the trip to the country ("Les Bacchanales") ${ }^{51}$; or the distancing - or even the self-sufficiency - are simply a fantasy: the poets' voyage to the îles Fortunées is merely Ronsard's vision; although "L'Isle pontine" has historical basis, the poem ends with a dream: that Ronsard and Du Bellay return to the island one day.

\section{Converging Threads}

This study of the presentation of poets' networks in the second half of the sixteenth century finds echoes in other converging analyses. In L'École des Muses, rather than focusing on references between poets of the "Pléiade," Jean-Charles Monferran is interested in

51 "Donque, puis que la nuit sombre, / Pleine d'ombre, / Vient les montaignes saisir, / Retournon troupe gentille / Dans la ville, / Demisoulez de plaisir. / Jamais l'homme tant qu'il meure, / Ne demeure / Fortuné parfaictement, Tousjours avec la lyesse / La tristesse / Se mesle segrettement" (So, since the sombre night, / Full of shadows, / Comes to seize the mountains, / Return my gentle troupe / To the city, / Renounce pleasure. / Never a man, before he dies, / could stay / Perfectly wealthy. / Always with joy / Sadness / Secretly mixes) (v. 631-642, final lines of the poem, Pierre de Ronsard (1921). in CEuvres complètes III, ed. P. Laumonier. Paris, Hachette: 216-217) 
(1549), l'Art poetique de Claude de Boissière (1554), L'Art poëtique de Jacques Peletier (1555) et quelques autres ouvrages théoriques, " cherche[nt] à circonscrire un champ propre à la poésie » (Monferran 2011: 17). Cela est renforcé par le recours à de nombreux exemples tirés des auteurs contemporains : Claude de Boissière renvoie, entre autres, à Ronsard, Le Caron et Denisot ; Jacques Peletier évoque la production de Ronsard, de Du Bellay, de Tyard, de Baîf, de Des Masures, de Jodelle mais aussi de Marot, d'Héroët et de Saint-Gelais. Ainsi ces publications cherchent-elles « conjointement, de façon alors tout à fait singulière, à délimiter un domaine propre aux lettres françaises et à organiser un Parnasse gaulois " (Monferran 2011: 17), puisque les auteurs présentés comme modèles sont sélectionnés parmi les contemporains estimés les plus exemplaires.

De son côté, Emmanuelle Mortgat-Longuet situe la Naissance de l'« histoire littéraire " française (2006) dans la seconde moitié du $\mathrm{xVI}^{\mathrm{e}}$ siècle, et souligne que cette naissance se fait dans le milieu intellectuel qui entoure la «Pléiade » (Charles de La Mothe, Étienne Pasquier, Claude Fauchet). L'enjeu est d'édifier des lettres modernes françaises « dont la reconnaissance n'était pas évidente » (Mortgat-Longuet 2006 : 11). Cette naissance s'explique, selon elle, par la volonté de « réparer » en quelque sorte les dégâts des guerres de religion en donnant la représentation d'une identité culturelle française.

Dans les deux cas, ces chercheurs s'intéressent aux représentations que donnent les théoriciens et historiens de la seconde moitié du $\mathrm{XVI}^{\mathrm{e}}$ siècle de l'activité poétique de leur temps, et ils soulignent tous deux la singularité de ce moment «Pléiade » qui voit se développer les textes qui circonscrivent un espace poétique français doté d'une histoire et d'un canon composé de poètes contemporains. poetry of the 1550s which promotes contemporary productions. He claims that Sébillet's Art poetique françois (1548), Du Bellay's Deffence (1549), Claude de Boissière's Artpoetique (1554), Jacques Peletier's Art poëtique (1555), and several other theoretical works "seek to define a field specific to poetry" (Monferran 2011: 17). This is reinforced by the use of many examples from contemporaries: Claude de Boissière refers to Ronsard, Le Caron, and Denisot among others; Jacques Peletier evokes the production of Ronsard, Du Bellay, de Tyard, de Baïf, de Des Masures, and de Jodelle, but also Marot, d'Héroët and Saint-Gelais. Thus, these publications seek to "collaboratively delineate a unique sphere for French literature, in a completely unique way, and to create France's own Parnassus" (Monferran 2011: 17), since those poets presented as examples, are chosen among contemporaries deemed to be the most exemplary.

Emmanuelle Mortgat-Longuet (2006) thinks that the birth of "the history of (French) literature" takes place in the second half of the sixteenth century, in the intellectual milieu surrounding the "Pléiade" (Charles de La Mothe, Étienne Pasquier, Claude Fauchet). The aim is to establish a modern French literature as its "recognition was not readily apparent" (Mortgat-Longuet 2006: 11). This emergence can be explained, according to her, by the desire to in some way "repair" the damage of the Wars of Religion through the representation of a French cultural identity.

In these two cases, researchers are interested in theorists and historians' representations in the second half of the sixteenth century of the poetic activity of their time; they both emphasize the uniqueness of the "Pléiade" period, which sees the creation of texts establishing a space for French poetry with its own history and a canon composed of contemporary poets. Certainly, 
Assurément, ces représentations se nourrissent de celles que les poètes ont données de leurs propres activités. D'ailleurs, plusieurs des auteurs d'arts poétiques ou d'histoire littéraire sont eux-mêmes poètes (Jacques Peletier, Étienne Pasquier). D'autres reprennent à leur compte les visions de l'histoire littéraire livrées par les poètes: Charles de La Mothe dans sa préface à l'édition posthume des œuvres de Jodelle en $1574^{50}$, par exemple, fait sienne la conception très " sélective » de l'histoire littéraire qu'ont voulu imposer Du Bellay, Ronsard et ses amis à leurs débuts, en affirmant que leurs prédécesseurs n'avaient pas fait grand-chose de valable et que la vraie grande poésie française allait commencer

avec eux

Nos travaux sur les représentations que les poètes de la seconde moitié $d u x v l^{e}$ siècle donnent de leur activité - représentations qui informent en partie les productions des théoriciens contemporains et des premiers historiens de la littérature - peuvent ainsi venir enrichir la compréhension de ce moment particulier de l'histoire littéraire. La réflexion des lettrés sur la place et la valeur de la poésie, l'édification d'une image des lettres françaises par les efforts conjoints des poètes, des théoriciens et des historiens, ainsi que la volonté des poètes de mettre en scène le réseau qu'ils forment, créent sans doute le terreau dans lequel s'enracinera la nouvelle configuration de la vie littéraire du XVII ${ }^{\mathrm{e}}$ siècle qu'a mise au

jour Alain Viala (1985).

50 Charles de La Mothe (1966) [1868]. « De la poesie françoise et des œuvres d'Estienne Jodelle, sieur du Lymodin ". In Les CEuvres \& Meslanges Poetiques d'Estienne Jodelle sieur du Lymodin, éd. Ch. Marty-Laveaux. Genève, Slatkine Reprints : 1-9. these representations are fuelled by those provided by the poets themselves of their own activity. Furthermore, many of those who write about poetry or literary history are themselves poets (Jacques Peletier, Étienne Pasquier). Others take up poets' visions of literary history on their behalf: in his preface to the posthumous edition of the works of Jodelle in $1574,{ }^{52}$ for example, Charles de La Mothe appropriates the very "selective" understanding of literary history which Du Bellay, Ronsard, and friends wished to impose when they set out, declaring that their predecessors had not done much of value and that the true great French poetry would begin with them.

This work on poets' representations of their own activity in the second half of the sixteenth century - representations which partly informed the productions of contemporary theorists and the first historians of literature - can thus enrich our understanding of this particular moment in literary history. Men and women of letters' reflection on the place and value of poetry, the establishment of an image of French literature by the collective efforts of poets, theorists, and historians, as well as the poets' will to present the network they formed, undoubtedly created the ground in which is rooted the new configuration of seventeenth-century literary life, as brought to light by Alain Viala (1985).

52 Charles de La Mothe (1966) [1868]. "De la poesie françoise et des œuvres d'Estienne Jodelle, sieur du Lymodin." In Les CEuvres \& Meslanges Poetiques d'Estienne Jodelle sieur du Lymodin, ed. Ch. Marty-Laveaux. Geneva, Slatkine Reprints: 1-9. 


\section{Conclusion}

En somme, la base «RéseauxPoètesXVI » est un outil pour l'approche quantitative des sociabilités littéraires mises en scène dans un corpus de publications datées de 1549 à 1586 . Elle permet de reconstituer le réseau de citations entre poètes et d'en interroger les évolutions sur trente-cinq ans, soit sur deux générations poétiques. Comme elle donne aussi accès aux textes, approches quantitatives et qualitatives peuvent se mêler pour retisser le maillage serré et complexe des affinités et des inimitiés affichées entre pairs. De la sorte, les imaginaires groupaux de la Brigade et de la Pléiade peuvent être situés à leur juste place : d'une part, au sein de représentations groupales nombreuses et articulées à des critères variés comme celui de l'ancrage géographique ou d'un chiffre symbolique $(7,9$, 12) ; d'autre part, au sein d'un vaste réseau de citations entre gens de plume qui intègre des poètes peu connus de nos jours ainsi que des poétesses, toutes et tous reliés de manière plus ou moins directe à cette troupe « des bons ${ }^{51}$ » que l'histoire littéraire a retenue.

$\mathrm{Si}$ «RéseauxPoètesXVI » permet de mesurer les relations affichées entre poètes, l'intensité des transferts de crédits, la centralité des uns ou la marginalité des autres, la base de données permet aussi et surtout de mesurer l'importance que la mise en scène des poètes en groupe, ainsi que la publication des dialogues entre pairs par écrits interposés, a eue pour la génération «Pléiade » et ses successeurs. De la sorte, le monde des lettres se donne à lire dans son fonctionnement réticulaire. Le corpus retenu ne doit pas faire oublier que les pièces sélectionnées côtoient en réalité, dans les recueils dont elles sont extraites, de nombreuses pièces adressées aux puissants qui sont un soutien économique indispensable pour

51 Voir cette expression dans les vers de Ronsard cités ci-dessus dans la section « Réseaux de citations, reconnaissance et économie du don ».

\section{Conclusion}

In summary, the "RéseauxPoètesXVI" database is a tool for a quantitative approach to literary sociability as presented in a body of publications dating from 1549 to 1586 . It allows to recreate a network of citations among poets and investigate its development over thirty-five years, that is to say over two generations of poets. Since it also gives access to the texts, quantitative and qualitative approaches can be combined to reconstruct the tight and complex mesh of affinities and enmities displayed between peers. In so doing, the imaginary groupings of the Brigade and the Pléiade may be situated in their true place: on the one hand, within numerous group representations and linked to various criteria such as that of geography or a symbolic number $(7,9,12)$; on the other hand, within a vast network of citations between authors, which includes poets - among them, some women - who are little-known today, all connected more or less directly to this group of the "bons" (fine poets) ${ }^{53}$ which literary history has retained.

While "RéseauXPoètesXVI" can measure relations as presented between poets; the intensity of transfers of credit; and the centrality or marginality of poets, the database's ultimate value is its ability to measure the importance, both for the "Pléiade" generation and its successors, of the presentation of poets as a group and of the publication of their texts as part of a dialogue between peers. The literary world can thus be seen as a reticulate. We should not forget that the poems selected from the collections would in reality sit alongside many other poems addressed to powerful people who are then an indispensable economic support for the poets. While there is as yet no autonomization of the literary field, poets' efforts to show themselves to be connected to one another help bring a

53 See this expression by Ronsard above in 1.2. 
les poètes. Sans qu'il y ait donc encore d'autonomisation du champ littéraire fortement engagée, les efforts des poètes pour se représenter en lien les uns avec les autres contribuent à donner une visibilité et une légitimité à ce domaine spécifique que sont les lettres françaises. Si l'on y ajoute l'entreprise des théoriciens amis de la «Pléiade » qui citent en exemple les productions poétiques de leurs contemporains, et l'émergence des premiers historiens de la littérature qui valorisent des auteurs de la Renaissance française comme autorités, on voit se mettre en place une organisation de la vie littéraire qui pourra se développer et s'émanciper au $\mathrm{XVII}^{\mathrm{e}}$ siècle pour donner de la consistance à un espace social assez autonome pour constituer ce

qu'Alain Viala a considéré comme un premier « champ littéraire ». visibility and legitimacy to the specific domain of French literature. If we add to this the work of theorist friends of the "Pléiade" who cite the poetic productions of their contemporaries as examples, and the emergence of the first historians of literature who highlight French Renaissance writers as authorities, we see the implementation of an organisation of literary life which would develop and free itself in the seventeenth century to give consistence to a fairly autonomous social space, to constitute what Alain Viala considered as a first "literary field."
Figure 7. Montage personnel à partir de portraits gravés d'auteurs de la Renaissance figurant dans des éditions du $x v^{e}$ siècle
Florence Bonifay Université Lyon 2 - Institut de la Communication ICOM
Florence Bonifay

Université Lyon 2 - Institut de la Communication ICOM
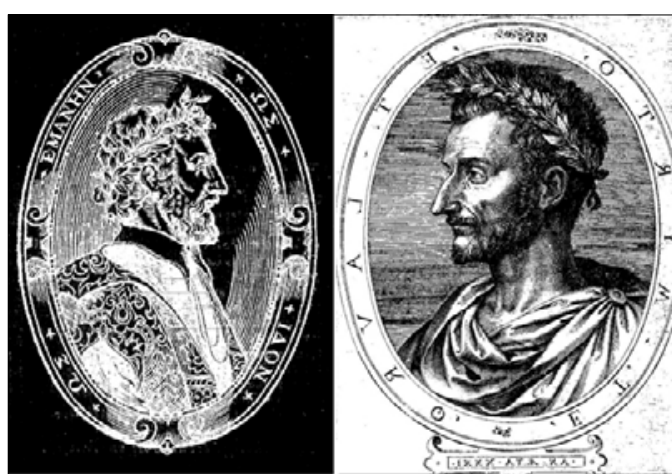

(a)

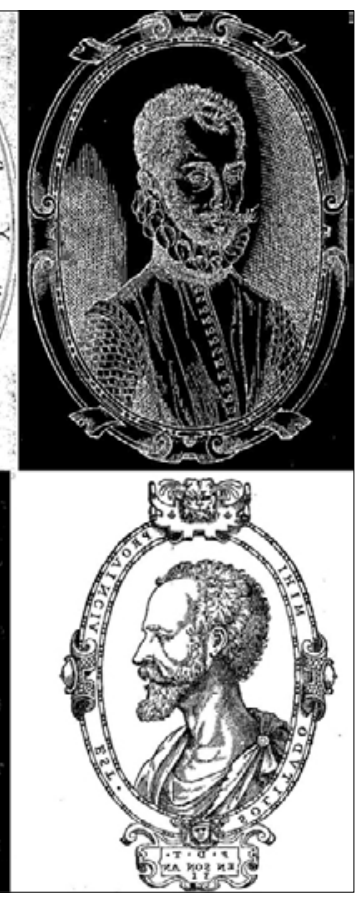

Figure 7. Photo-montage by Florence Bonifay, using sixteenth-century engraved portraits of Renaissance authors 


\section{Références bibliographiques}

Alduy Cécile (2007). Politique des « Amours ». Poétique et genèse d'un genre français nouveau (1544-1560). Genève, Droz.

Balmas Enea (1965). « II mito della Pleiade ». Saggi e Ricerche di Letteratura francese, vol. IV : 11-36.

BERRIET Thomas (2009). « Le prix du don : de l'éloge au blâme chez Pierre de Ronsard », CONTEXTES, 5, « Don et littérature ». [En ligne] http://contextes.revues.org/4279 [consulté le 15 janvier 2018].

Berthon Guillaume (2014). L'Intention du poète. Clément Marot « autheur ». Paris, Garnier.

BONIFAY Florence (2016). " "RéseauxPoètesXVI" : une base de données pour étudier les réseaux de poètes au Xvi siècle en France ". Le Réseau. Usage d'une notion polysémique en sciences humaines et sociales. Louvain-la-Neuve, Presses Universitaires de Louvain : 27-41.

BOURDIEU Pierre (1982). « Le capital social ». Actes de la recherche en sciences sociales, $31: 2-3$

BOURDIEU Pierre (1991). « Le champ littéraire ». Actes de la recherche en sciences sociales, $89: 4-46$.

BouRdieu Pierre (1992). Les Règles de l'art. Genèse et structure du champ littéraire. Paris, Seuil.

BURON Emmanuel (2006). « Le mythe du salon de la maréchale de Retz. Éléments pour une sociologie de la littérature à la cour des derniers Valois ». Henri III mécène des arts, des sciences et des lettres. Paris, Presses Universitaires Paris-Sorbonne : 306-315

Chamard Henri (1939-1940). Histoire de la Pléiade, tome 1 à 4. Paris, Didier

\section{References}

Alduy Cécile (2007). Politique des "Amours." Poétique et genèse d'un genre français nouveau (1544-1560). Geneva, Droz.

BALmAS Enea (1965). "II mito della Pleiade," Saggie Ricerche di Letteratura francese, vol. IV: 11-36.

BerRiet Thomas (2009). "Le prix du don: de l'éloge au blâme chez Pierre de Ronsard." COnTEXTES, 5, "Don et littérature." [On line] http:// contextes.revues.org/4279 [accessed on 15 january 2018].

BerTHON Guillaume (2014). L'Intention du poète. Clément Marot "autheur." Paris, Garnier.

BONIFAY Florence (2016). "'RéseauxPoètesXVl': une base de données pour étudier les réseaux de poètes au $\mathrm{XV}^{\mathbb{E}}$ siècle en France." Le Réseau. Usage d'une notion polysémique en sciences humaines et sociales. Leuven, Presses Universitaires de Louvain: 27-41.

BOURDIEU Pierre (1982). "Le capital social." Actes de la recherche en sciences sociales, 31: 2-3.

BouRdieu Pierre (1991). "Le champ littéraire." Actes de la recherche en sciences sociales, 89: 4-46.

Bourdieu Pierre (1996). The Rules of Art. Genesis and Structure of the Literary Field. English translation by Susan Emanuel. Palo Alto, Stanford University Press.

Buron Emmanuel (2006). "Le mythe du salon de la maréchale de Retz. Éléments pour une sociologie de la littérature à la cour des derniers Valois." Henri III mécène des arts, des sciences et des lettres. Paris, Presses Universitaires Paris-Sorbonne: 306-315.

Chamard Henri (1939-1940). Histoire de la Pléiade, tome 1 à 4. Paris, Didier. 
Charton-Le-CleCh Sylvie (1993). Chancellerie et culture au xvi siècle (les notaires et les secrétaires du roi de 1515 à 1547). Toulouse, Presses Universitaires du Mirail.

CLÉMENT Michèle (2010). « Nom d'auteur et identité littéraire : Louise Labé Lyonnaise. Sous quel nom être publiée en France au XVle siècle ? ». Réforme, Humanisme, Renaissance, 70 : 73-101.

Creore Alvin Emerson (1972). A Word-Index to the Poetic Works of Ronsard, t. 2. Leeds, W.S. Maney and Son LTD.

Dozo Björn-Olav, Glinoer Anthony, LACROIx Michel (2012). Imaginaires de la vie littéraire. Fiction, figuration, configuration. Rennes, Presses Universitaires de Rennes (PUR).

FragonaRD Marie-Madeleine (1992). « Stratégie de la diffamation et poétique du monstrueux : D’Aubigné et Henri III ». Henri III en son temps. Paris, Vrin : 47-56.

Gadoffre Gilbert (1997). La Révolution culturelle dans la France humaniste. Genève, Droz.

GOYET Francis (2003). Commentaire de La Deffence dans Joachim Du BelLay. CEuvres complètes I, éd. Olivier Millet. Paris, Champion.

HeINICH Nathalie (2000). Être écrivain. Création et identité. Paris, La Découverte.

JoUkovSKY Françoise (1969). La Gloire dans la poésie française et néolatine $d u \mathrm{xvl}^{\mathrm{e}}$ siècle. Genève, Droz.

LAHIRE Bernard (2012). Monde pluriel. Penser l'unité des sciences sociales. Paris, Seuil.
ChARTON-Le-CleCH Sylvie (1993). Chancellerie et culture au XVI ${ }^{\mathrm{e}}$ siècle (les notaires et les secrétaires du roi de 1515 à 1547). Toulouse, Presses Universitaires du Mirail.

ClÉmENT Michèle (2010). "Nom d'auteur et identité littéraire: Louise Labé Lyonnaise. Sous quel nom être publiée en France au $\left.\mathrm{XVI}\right|^{\mathrm{e}}$ siècle ?". Réforme, Humanisme, Renaissance, 70: 73-101.

Creore Alvin Emerson (1972). A Word-Index to the Poetic Works of Ronsard, t. 2. Leeds, W.S. Maney and Son LTD.

Dozo Björn-Olav, GlinOER Anthony, LACRoIx Michel (2012). Imaginaires de la vie littéraire. Fiction, figuration, configuration. Rennes, Presses Universitaires de Rennes (PUR).

FragonARD Marie-Madeleine (1992). "Stratégie de la diffamation et poétique du monstrueux: D’Aubigné et Henri III." Henri III en son temps. Paris, Vrin: 47-56.

Gadoffre Gilbert (1997). La Révolution culturelle dans la France humaniste. Geneva, Droz.

GOYET Francis (2003). Commentaire de La Deffence dans Joachim Du Bellay. CEuvres complètes I, éd. Olivier Millet. Paris, Champion.

HEINICH Nathalie (2000). Être écrivain. Création et identité. Paris, La Découverte.

JouKovSKy Françoise (1969). La Gloire dans la poésie française et néolatine $d u x_{\mathrm{XV}}{ }^{\mathrm{e}}$ siècle. Geneva, Droz.

LAHIRE Bernard (2012). Monde pluriel. Penser l'unité des sciences sociales. Paris, Seuil. 
LAUFER Roger (1989) [1982]. « L'espace visuel du livre ancien 》. In ChARTIER Roger \& MARTIN Henri-Jean. Histoire de l'édition française. Le livre conquérant, du Moyen Âge au milieu du XVII siècle. Paris, Fayard.

LebĖGue Raymond (1966). « De la Brigade à la Pléiade ». Lumières de la Pléiade. Paris, Vrin : 13-20.

MAIRA Daniel (2007). Typosine, la dixième muse. Formes éditoriales des canzonieri français (1544-1560). Genève, Droz.

Mathieu-Castellani Gisèle (1986). « Poésie et spécularité : la représentation de l'écriture dans les "Amours" de Cassandre ". Revue d'histoire littéraire de la France, 86(4) : 659-666.

Mauss Marcel (2012) [1925]. Essai sur le don. Forme et raison de l'échange dans les sociétés archaïques, éd. Florence Weber. Paris, Presses Universitaires de France (PUF).

MolinIÉ George \& VIALA Alain (1993). Approches de la réception. Sémiostylistique et sociopoétique de Le Clézio. Paris, Presses Universitaires de France (PUF).

MonferRAN Jean-Charles (2011). L'École des Muses. Les arts poétiques français à la Renaissance (1548-1610). Sébillet, Du Bellay, Peletier et les autres. Genève, Droz.

Mortgat-Longuet Emmanuelle (2006). Clio ou Parnasse. Naissance de $l^{\prime}$ " histoire littéraire » française aux $\mathrm{XVI}^{\mathrm{e}}$ et $\mathrm{xVII}{ }^{\mathrm{e}}$ siècles. Paris, Champion.

PreISIG Florian (2004). Clément Marot et les métamorphoses de l'auteur à l'aube de la Renaissance. Genève, Droz.

ROUGET François (2009). « Jean-Antoine de Baïf et l'Académie du Palais ». Revue d'histoire littéraire de la France, 109(2) : 385-402.
LAUFER Roger (1989) [1982]. "L'espace visuel du livre ancien.” In CHARTIER Roger \& MARTIN Henri-Jean. Histoire de l'édition française. Le livre conquérant, du Moyen Âge au milieu du $\mathrm{XVII}^{\mathrm{e}}$ siècle. Paris, Fayard.

LeBĖGue Raymond (1966). "De la Brigade à la Pléiade." Lumières de la Pléiade. Paris, Vrin: 13-20.

MAIRA Daniel (2007). Typosine, la dixième muse. Formes éditoriales des canzonieri français (1544-1560). Geneva, Droz.

Mathieu-Castellani Gisèle (1986). "Poésie et spécularité: la représentation de l'écriture dans les 'Amours' de Cassandre." Revue d'histoire littéraire de la France, 86(4): 659-666.

Mauss Marcel (2001). The Gift: The Form and Reason for Exchange in Archaic Societies. Translated by W.D. Halls. London, Routledge.

MOLINIÉ George \& VIALA Alain (1993). Approches de la réception. Sémiostylistique et sociopoétique de Le Clézio. Paris, Presses Universitaires de France (PUF).

MonferRan Jean-Charles (2011). L'École des Muses. Les arts poétiques français à la Renaissance (1548-1610). Sébillet, Du Bellay, Peletier et les autres. Geneva, Droz.

Mortgat-Longuet Emmanuelle (2006). Clio ou Parnasse. Naissance de I'“histoire littéraire" française aux $\mathrm{XVI}^{\mathrm{e}}$ et $\mathrm{xVII}{ }^{\mathrm{e}}$ siècles. Paris, Champion.

Preisig Florian (2004). Clément Marot et les métamorphoses de l'auteur à l'aube de la Renaissance. Geneva, Droz.

Rouget François (2009). "Jean-Antoine de Baïf et l'Académie du Palais." Revue d'histoire littéraire de la France, 109(2): 385-402. 
SAINT-Amand Denis (2013). «Piston et dithyrambes. Ce que l'amitié fait aux groupes littéraires». Communication du 14 juin 2013. [En ligne : audible en podcast sur le site du GREMLIN] : http://legremlin.org/index. php/passees/lienmenujourneeamities [consulté le 15 janvier 2018]

SIMONIN Michel (1990). Pierre de Ronsard. Paris, Fayard.

SIMONIN Michel (2004) [1985]. «Ronsard encomiaste : la rhétorique de l'éloge dans les pièces liminaires ». L'Encre \& la lumière. Quarante-sept articles (1976-2000). Genève, Droz : 335-350.

SkENAZI Cynthia (2003). " L'économie du don et le mécénat : les formes de l'échange dans une épître de Clément Marot ». French studies, 57 463-474.

TROTот Caroline (2008). « La détermination du champ littéraire entre rhétorique et poétique autour de la Pléiade ». In CHIRON Pierre \& CLAUDON Francis (dir.). Constitution du champ littéraire. Limites, intersections, déplacements. Paris, L'Harmattan : 191-207.

VIALA Alain (1985). Naissance de l'écrivain. Sociologie de la littérature à l'âge classique. Paris, Minuit.

VialA Alain (2014). Le Moyen Âge et la Renaissance. Paris, Presses Universitaires de France (PUF).

VIGNES Jean (2004). «Les modes de diffusion du texte poétique dans la seconde moitié du XVI ${ }^{e}$ siècle : essai de typologie ». In GIROT Jean-Eudes (dir.). Le Poète et son œuvre. De la composition à la publication. Genève, Droz : 173-198.

VIGNES Jean (2007). " L'éclat de la Pléiade : un programme ambitieux (1549-1578) ». In JARRETY Michel (dir.). La Poésie française du Moyen Âge au $X X^{e}$ siècle. Paris, Presses Universitaires de France (PUF).

Zemon Davis Natalie (2003). Essai sur le don dans la France du XVI e siècle. Traduit en français par Denis Trierweiler. Paris, Seuil.
SAINT-Amand Denis (2013). "Piston et dithyrambes. Ce que l'amitié fait aux groupes littéraires." Communication du 14 juin 2013. [On line: podcast on the GREMLIN site]: http://legremlin.org/index.php/passees/ lienmenujourneeamities [accessed on 15 january 2018].

SIMONIN Michel (1990). Pierre de Ronsard. Paris, Fayard.

SIMONIN Michel (2004) [1985]. "Ronsard encomiaste: la rhétorique de l'éloge dans les pièces liminaires." L'Encre \& la lumière. Quarante-sept articles (1976-2000). Geneva, Droz: 335-350.

SkENAZI Cynthia (2003). "L'économie du don et le mécénat: les formes de l'échange dans une épître de Clément Marot." French studies, 57: 463474.

TROTOт Caroline (2008). "La détermination du champ littéraire entre rhétorique et poétique autour de la Pléiade." In CHIRON Pierre \& CLAUDON Francis (eds.). Constitution du champ littéraire. Limites, intersections, déplacements. Paris, L’Harmattan: 191-207.

VIALA Alain (1985). Naissance de l'écrivain. Sociologie de la littérature à l'âge classique. Paris, Minuit.

VIALA Alain (2014). Le Moyen Âge et la Renaissance. Paris, Presses Universitaires de France (PUF).

VIGNES Jean (2004). "Les modes de diffusion du texte poétique dans la seconde moitié du XVI e siècle: essai de typologie." In GIROT Jean-Eudes (ed.). Le Poète et son œuvre. De la composition à la publication. Geneva, Droz: $173-198$

VIGNES Jean (2007). "L'éclat de la Pléiade: un programme ambitieux (1549-1578)." In JaRRETY Michel (ed.). La Poésie française du Moyen Âge au $x X^{e}$ siècle. Paris, Presses Universitaires de France (PUF).

Zemon Davis Natalie (2000). The Gift in Sixteenth-Century France. Madison, University of Wisconsin Press. 